University of Nebraska - Lincoln

DigitalCommons@University of Nebraska - Lincoln

\title{
Topographic, Bioclimatic, and Vegetation Characteristics of Three Ecoregion Classification Systems in North America: Comparisons Along Continent-wide Transects
}

\author{
Robert Thompson \\ US Geological Survey \\ Sarah Shafer \\ US Geological Survey \\ Katherine Anderson \\ US Geological Survey \\ Laura Strickland \\ US Geological Survey \\ Richard Pelltier \\ US Geological Survey \\ See next page for additional authors \\ Follow this and additional works at: https://digitalcommons.unl.edu/usgsstaffpub \\ Part of the Earth Sciences Commons
}

Thompson, Robert; Shafer, Sarah; Anderson, Katherine; Strickland, Laura; Pelltier, Richard; Bartlein, Patrick; and Kerwin, Michael, "Topographic, Bioclimatic, and Vegetation Characteristics of Three Ecoregion Classification Systems in North America: Comparisons Along Continent-wide Transects" (2005). USGS Staff -- Published Research. 15.

https://digitalcommons.unl.edu/usgsstaffpub/15

This Article is brought to you for free and open access by the US Geological Survey at DigitalCommons@University of Nebraska - Lincoln. It has been accepted for inclusion in USGS Staff -- Published Research by an authorized administrator of DigitalCommons@University of Nebraska - Lincoln. 


\section{Authors}

Robert Thompson, Sarah Shafer, Katherine Anderson, Laura Strickland, Richard Pelltier, Patrick Bartlein, and Michael Kerwin 


\section{Topographic, Bioclimatic, and Vegetation Characteristics of Three Ecoregion Classification Systems in North America: Comparisons Along Continent-wide Transects}

\author{
ROBERT S. THOMPSON* \\ SARAH L. SHAFER \\ KATHERINE H. ANDERSON ${ }^{\dagger}$ \\ LAURA E. STRICKLAND \\ RICHARD T. PELLTIER \\ US Geological Survey \\ Earth Surface Processes Team \\ Box 25046, MS 980, DFC \\ Denver, Colorado 80225, USA
}

\section{PATRICK J. BARTLEIN}

Department of Geography

University of Oregon

Eugene, Oregon 97403, USA

\section{MICHAEL W. KERWIN}

Department of Geography

University of Denver

Denver, Colorado 80208, USA

ABSTRACT / Ecoregion classification systems are increasingly used for policy and management decisions, particularly among conservation and natural resource managers. A number of ecoregion classification systems are currently available, with each system defining ecoregions using dif- ferent classification methods and different types of data. As a result, each classification system describes a unique set of ecoregions. To help potential users choose the most appropriate ecoregion system for their particular application, we used three latitudinal transects across North America to compare the boundaries and environmental characteristics of three ecoregion classification systems [Küchler, World Wildlife Fund (WWF), and Bailey]. A variety of variables were used to evaluate the three systems, including woody plant species richness, normalized difference in vegetation index (NDVI), and bioclimatic variables (e.g., mean temperature of the coldest month) along each transect. Our results are dominated by geographic patterns in temperature, which are generally aligned north-south, and in moisture, which are generally aligned east-west. In the west, the dramatic changes in physiography, climate, and vegetation impose stronger controls on ecoregion boundaries than in the east. The Küchler system has the greatest number of ecoregions on all three transects, but does not necessarily have the highest degree of internal consistency within its ecoregions with regard to the bioclimatic and species richness data. In general, the WWF system appears to track climatic and floristic variables the best of the three systems, but not in all regions on all transects.
Over the past several decades, government agencies and conservation groups have increasingly used ecoregion classification systems to gain a better understanding of the lands, ecosystems, and species that they seek to manage and protect. A number of ecoregion concepts and "systems" have been developed to provide the necessary basis for policy, planning, and implementation of management and conservation plans. In

KEY WORDS: Ecoregions; North America; Küchler; World Wildlife Fund; Bailey

†Present address: INSTAAR, University of Colorado, Boulder, CO 80309.

Published online January 13, 2005.

*Author to whom correspondence should be addressed; email: rthompson@usgs.gov
North America, different land management agencies and conservation groups have selected different ecoregion systems for these purposes; for example, the US Forest Service developed and uses a system under the primary authorship of R. G. Bailey (Bailey 1983, 1984, 1997, 1998), whereas the US Environmental Protection Agency developed the system authored by J. M. Omernik (1987, 1995a, 1995b). Both systems have been used by conservation organizations: The Bailey system has been modified and used by The Nature Conservancy for ecoregional planning (Groves and others 2000), whereas the Omernik system has been modified and adapted for conservation purposes by the World Wildlife Fund (WWF) (Ricketts and others 1999a, 1999b).

Many of the ecoregion classification systems developed for North America are similar in some respects. 


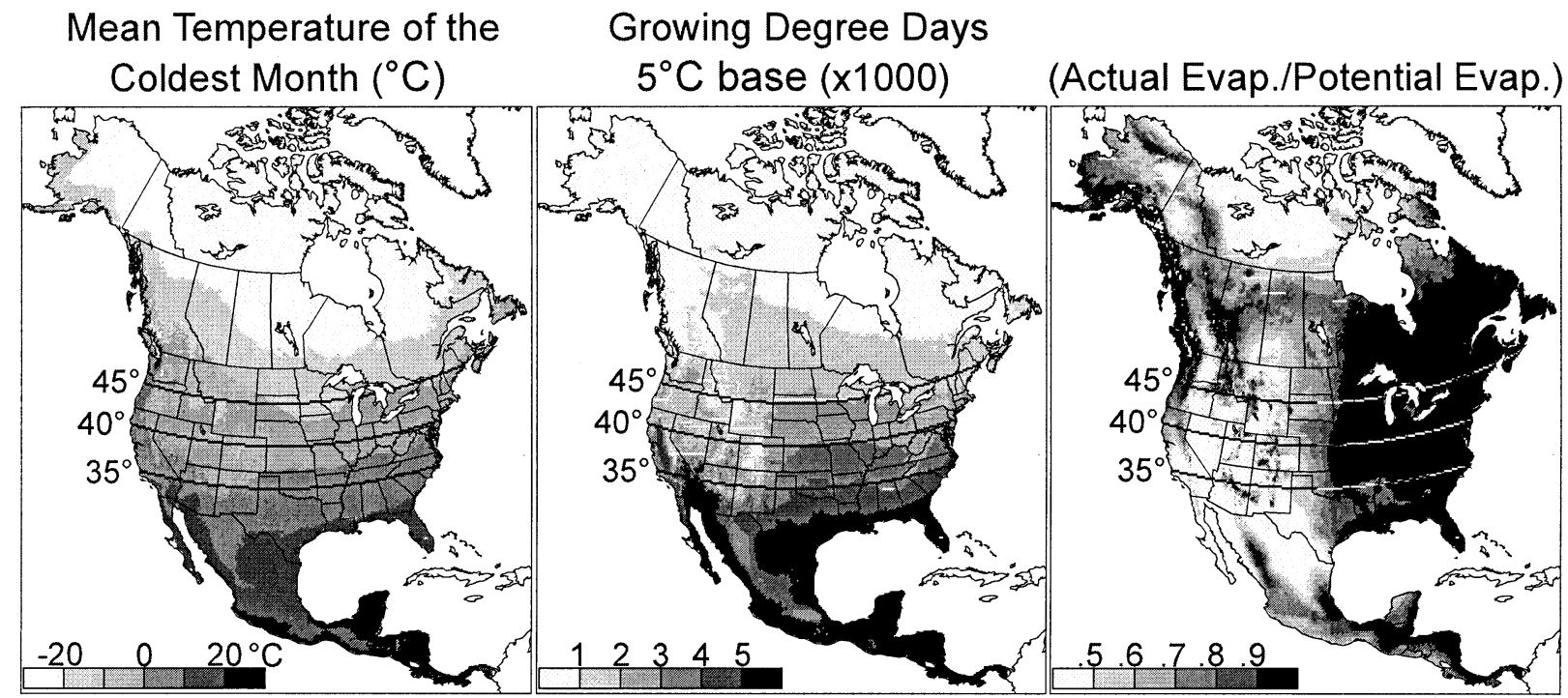

Figure 1. The 1951-1980 30-year mean North American distributions of the mean temperature of the coldest month (MTCO; left panel), growing degree-days on a $5^{\circ} \mathrm{C}$ base (GDD5; center panel), and $\alpha$, the moisture index (right panel). These data are from Thompson and others (1999a). The location of the three transects discussed in this report are shown as black (or white) stripes at $35^{\circ} \mathrm{N}$ (the subtropical transect), $40^{\circ} \mathrm{N}$ (the temperate transect), and $45^{\circ} \mathrm{N}$ (the temperate/subboreal transect).

For example, many ecoregion classification systems have ecoregion configurations that capture the dominant patterns of vegetation in North America, approximating the patterns found in Küchler's maps of potential natural vegetation (Küchler 1964, 1973, 1985, 1993) or in the distribution maps of trees and shrubs of E. L. Little, Jr. and colleagues (Little 1971, 1976, 1977, 1978, 1981). The major ecoregion classification systems differ from one another in several significant ways, however, due to differences in the underlying assumptions, goals, and individual choices of the various investigators employing the "art" of devising ecoregion boundaries. Given these differences, how should potential users choose which ecoregion system to employ in their work? This study explores the possibility of differentiating among the systems based on an analysis of ecoregion divisions, the nature of the boundaries between adjacent ecoregions, the internal consistency of geologic, climatic, vegetation, and floristic characteristics, and the identification of the dominant environmental factors determining ecoregion extents and boundaries.

In this article, we compare three ecoregion systems along three continental transects at approximately $35^{\circ} \mathrm{N}, 40^{\circ} \mathrm{N}$, and $45^{\circ} \mathrm{N}$ in subtropical, temperate, and temperate/subboreal North America (Figure 1). For each transect, we present data at $25-\mathrm{km}$ intervals on topography, bioclimate [mean temperature of the coldest month (MTCO), growing degree-days on a $5^{\circ} \mathrm{C}$ base (GDD5), and a moisture index $(\alpha)$ ], vegetation density [as represented by the Normalized Difference in Vegetation Index (NDVI)], and woody flora species richness. We also measure the similarity of the woody flora assemblages between adjacent points on the transects and within ecoregions using the Jaccard coefficient of similarity (Jaccard 1908). We use these data to compare the Küchler vegetation categories (for simplicity's sake, referred to in this article as an ecoregion system, although developed prior to the common application of the term "ecoregion"), the Bailey ecoregion system, and the WWF ecoregion system. These three systems (the internal boundaries of which are shown on the transects in Figures 2A, 6A, 10A) differ in concept in that the Küchler system is based solely on potential natural vegetation (Küchler 1964), although it indirectly integrates climate, soils, and other environmental variables that influence vegetation distribution. The Bailey system incorporates climate, topography, and vegetation (Bailey 1983, 1998). The Omernik system, on which the WWF system is partly based, integrates soils, land surface form, potential natural vegetation, land use, and other variables (Omernik 1987).

We compare these three ecoregion classification systems using two different types of analysis. The first analysis involves comparing adjacent grid points along each of the transects. This analysis examines the spatial trends along the transects as well as the nature of the 


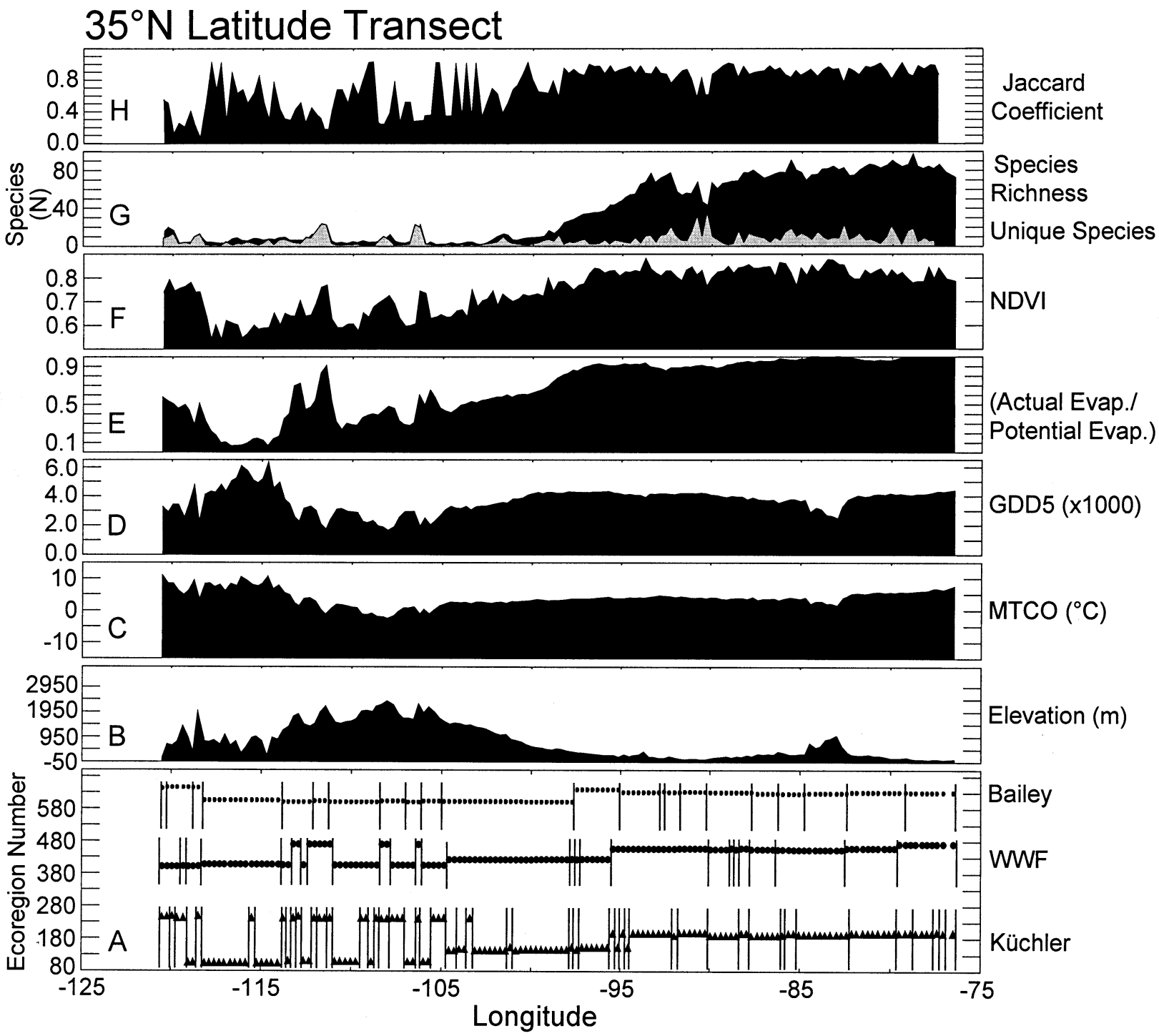

Figure 2. The $35^{\circ} \mathrm{N}$ (subtropical) transect of North America showing the 25-km grid points across the continent. This illustration is designed for point-to-point comparisons of adjacent points and for comparison of the elevation, bioclimatic, and floristic data with the ecoregion boundaries. For each transect grid point, the panels are as follows (from bottom to top): (A) The boundaries of the ecoregions encountered on this transect for the Küchler potential natural vegetation categories (bottom), the World Wildlife Fund (WWF) ecoregions (center), and the Bailey ecoregions (top). Vertical lines represent boundaries between ecoregions, and the greater the vertical offset between adjacent transect points, the greater the perceived ecoregion classification difference between these points. (See Table 1 for the list of ecoregions and ecoregion numbers.) (B) Elevation (m). (C) Mean temperature of the coldest month (MTCO). (D) Growing degree-days on a $5^{\circ} \mathrm{C}$ base (GDD5). (E) Moisture index $(\alpha)$. (F) Maximum value of the Normalized Difference in Vegetation Index (NDVI). (G) Number of woody species ("species richness"; black) and the number of unique species for each grid cell summed with the number of unique taxa in the grid cell directly to the east (gray). (H) Jaccard similarity coefficient as a measure of the similarity between each grid point and the adjacent point to the east.

transitions at ecoregion boundaries under each of the three ecoregion systems. The second analysis assesses the internal consistency of the environmental and floristic characteristics for each ecoregion encountered along the transects. This analysis addresses the question of whether any of the ecoregion systems are more internally consistent with regard to the bioclimatic and floristic data examined in this study. 


\section{Datasets}

We used a variety of environmental variables to analyze the ecoregions in this study. Variables were chosen that were considered to be important in defining ecoregion characteristics and boundaries. Each dataset used in this study, including the geographic information system (GIS) layers of the three ecoregion classification systems, was applied to a $25-\mathrm{km}$ equal-area grid of North America.

\section{Ecoregions}

We acquired GIS datasets of each of the three ecoregion systems analyzed in this study. From the "Potential Natural Vegetation of the Conterminous United States" dataset (Küchler 1964, 1993), we examined 61 vegetation types (ecoregions) for the conterminous United States; from the "Ecoregions of North America" dataset (Bailey 1997, 1998), we used the 30 province-level ecoregions; and from the "Terrestrial Ecoregions of the World" dataset (WWF; Olson and others 2001, adapted from Omernik 1995b), we used 44 ecoregions.

\section{Normalized Difference in Vegetation Index}

The Normalized Difference in Vegetation Index dataset (USGS and others 1997) was derived from 1-km Advanced Very High Resolution Radiometer (AVHRR) data spanning April 1992 through March 1993. Monthly NDVI composites were used to assign values ranging from 0 to 1 to each grid point on the three transects, where increasing NDVI values indicate increasing green vegetation, and zero values indicate nonvegetated features (such as water, ice, snow, or clouds).

\section{Elevation, Bioclimate, and Woody Flora}

Elevational, bioclimatic, and woody floristic data were from the Atlas of Relations Between Climatic Parameters and Distributions of Important Trees and Shrubs in North America (Thompson and others 1999a, 1999b, 2000). The elevational data were calculated by bilinearly interpolating elevations from the ETOPO5 dataset (Edwards 1992) to each $25-\mathrm{km}$ grid point in North America (Thompson and others 1999a). The bioclimatic data were calculated from a 1951-1980 30year mean monthly climate dataset developed by P. J. Bartlein and B. Lipsitz (University of Oregon) using data from more than 8000 North American weather stations (Thompson and others 1999a). Distances from the nearest weather stations and local elevational profiles were important determinants of the estimated climate at each $25-\mathrm{km}$ grid point [see
Thompson and others (1999a) for further discussion]. Three bioclimate variables were calculated from the 1951-1980 30-year mean climate data: the mean temperature of the coldest month (MTCO) (Prentice and others 1992), annual growing degree-days on a $5^{\circ} \mathrm{C}$ base (GDD5) (Newman 1980), and $\alpha$, an annual moisture index calculated as actual evaporation divided by potential evaporation (based on Thornthwaite and Mather 1955, 1957; Willmott and others 1981, 1985).

The woody floristic data from Thompson and others (1999a, 1999b, 2000) consisted of digitized present-day distributions of more than 600 woody species from the Atlas of United States Trees (Little 1971, 1976, 1977, 1978, 1981; Critchfield and Little 1966). Additional distribution data were obtained from Bailey (1970), Benson and Darrow (1981), and Yang (1970).

\section{Methods}

We carried out two basic analyses with the data described above. First, we did a point-to-point comparison analysis along transects formed of the nearest grid points to the latitudes of $35^{\circ} \mathrm{N}, 40^{\circ} \mathrm{N}$, and $45^{\circ} \mathrm{N}$. Second, we examined the internal consistency of the bioclimatic variables, species richness, and floristic content of each ecoregion encountered along each transect.

\section{Point-to-Point Comparisons}

The point-to-point comparison analysis used three latitudinal transects defined by choosing the nearest $25-\mathrm{km}$ grid points to $35^{\circ} \mathrm{N}, 40^{\circ} \mathrm{N}$, and $45^{\circ} \mathrm{N}$ across North America (Figure 1). The $35^{\circ} \mathrm{N}$ transect (Figures 2-5) represents the subtropical conditions in the southern United States, where mean winter temperatures remain above freezing. The $40^{\circ} \mathrm{N}$ transect (Figures 6-9) passes through temperate zones in the middle of the United States, where mean winter temperatures can commonly drop below freezing. The $45^{\circ} \mathrm{N}$ transect (Figures 10-13) passes through temperate and subboreal regions in the northern contiguous United States and adjacent eastern Canada, where severe winters are more common along most of the transect. The longitudinal breadth of the three transects (literally from ocean to ocean) provides a wide range of moisture and physiographic conditions, with the 100th meridian being the general dividing line between the relatively humid moisture conditions and low topographic variability of the "East" and the generally semiarid to arid moisture conditions and high topographic variability of the "West" (Powell 1878). We did not evaluate transects from farther north or 


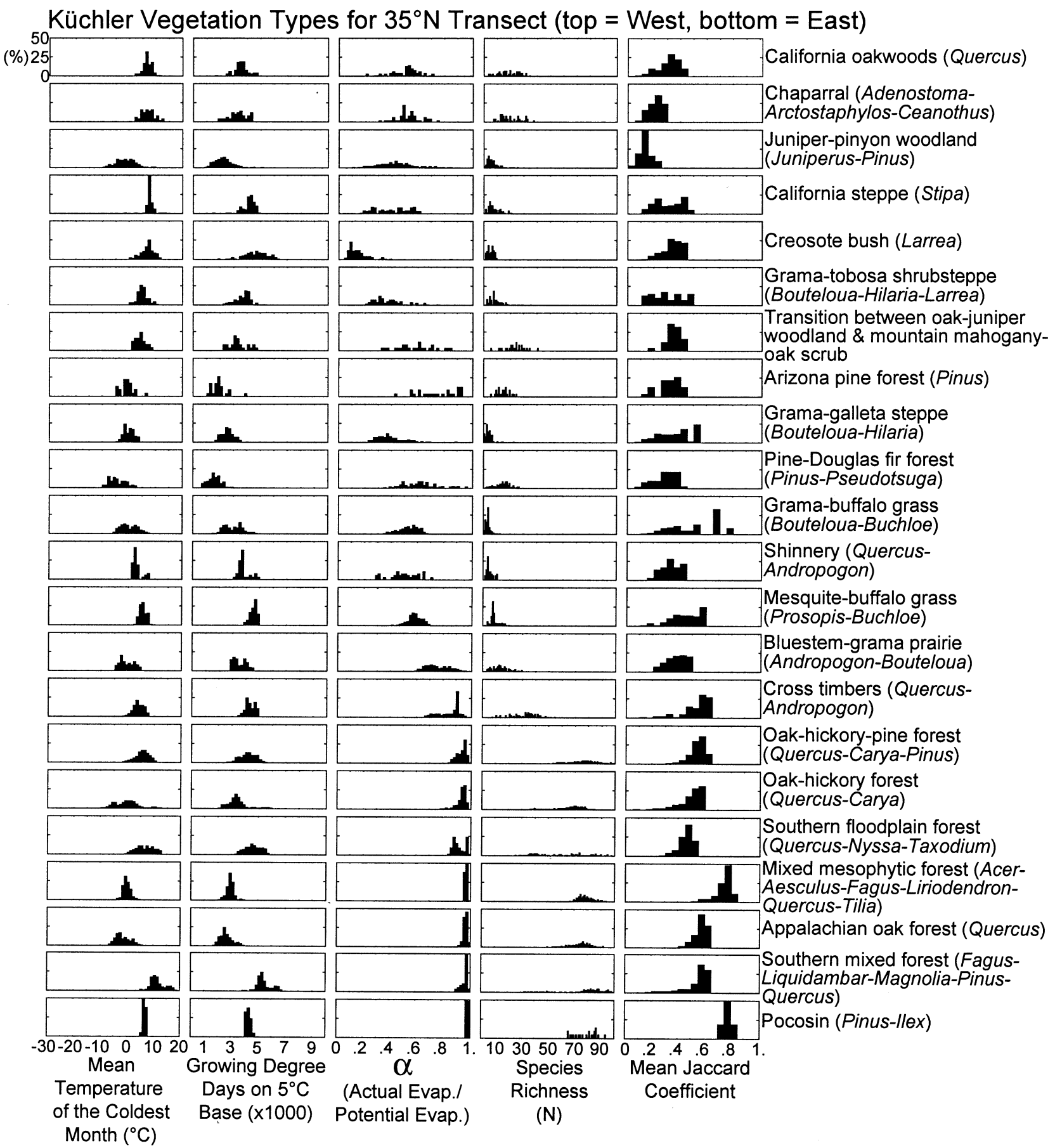

Figure 3. Histograms illustrating the degree of internal consistency of the bioclimatic, species richness, and woody flora data for Küchler ecoregions encountered on the $35^{\circ} \mathrm{N}$ transect from west to east (top to bottom). The vertical bars of the histograms illustrate the proportion of the total range of the ecoregion (with regard to a given variable) that occurs within the width of the bar on the $x$-axis [see Thompson and others (1999a) for greater detail]. If a given ecoregion occurs more than once on the transect, it is shown only once (in its westernmost position). The five vertical sets of panels are (from left to right) MTCO, GDD5, $\alpha$, species richness, and the mean Jaccard similarity coefficient.

farther south because our climate and floristic data are not as robust in tropical and boreal regions as they are in the subtropical to subboreal latitudes of North America. 


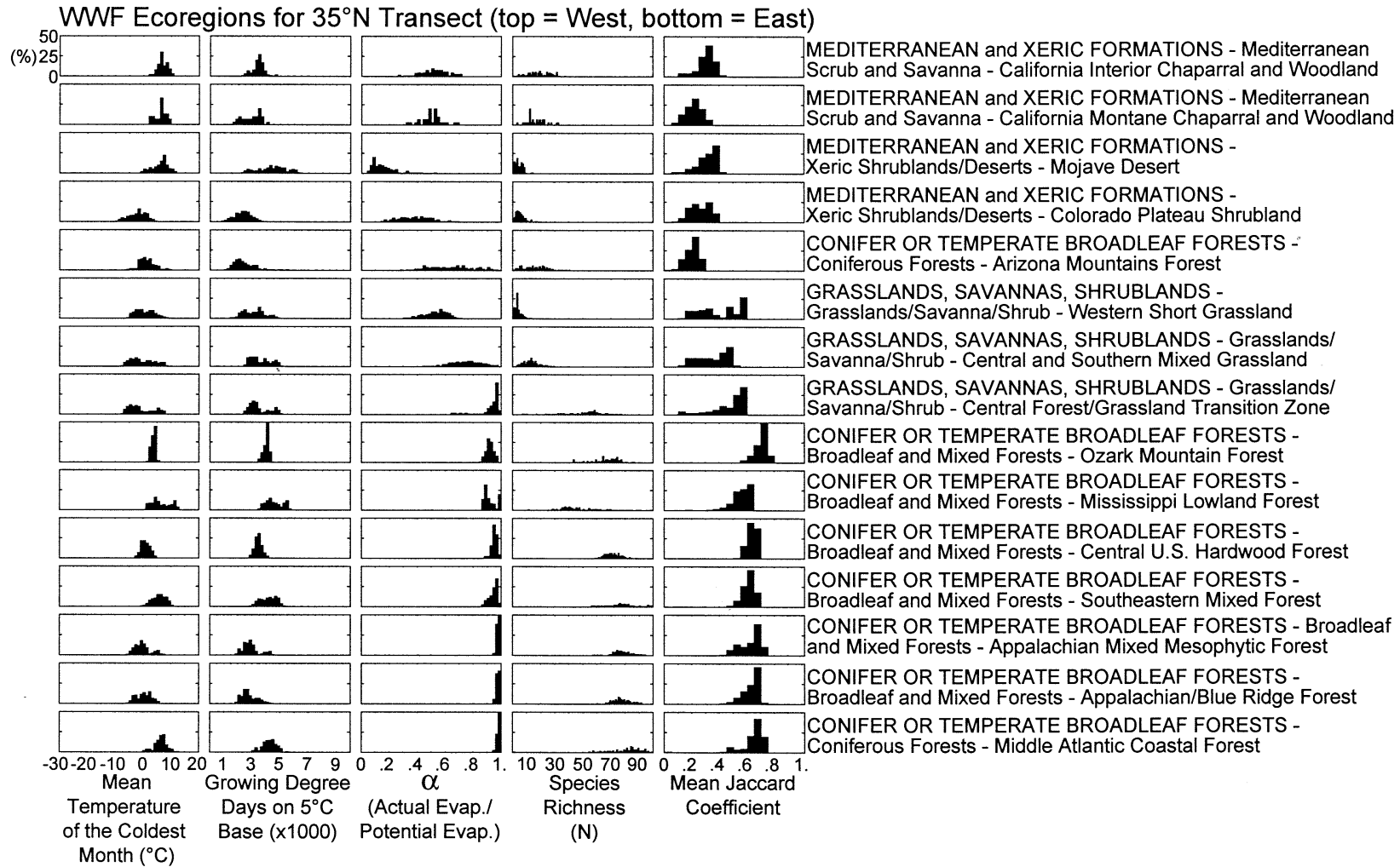

Figure 4. Histograms illustrating the degree of internal consistency of the bioclimatic, species richness, and woody flora data for WWF ecoregions encountered on the $35^{\circ} \mathrm{N}$ transect from west to east (top to bottom). See Figure 3 for a description of the histograms.

For the point-to-point analyses, we plotted the following data along each transect (Figures 2, 6, and 10):

A. Boundaries between adjacent ecoregions (Küchler on the bottom, WWF in the center, Bailey on top)

B. Elevation $(\mathrm{m})$

C. Mean temperature of the coldest month (MTCO; ${ }^{\circ} \mathrm{C}$ )

D. Growing degree-days on a $5^{\circ} \mathrm{C}$ base (GDD5) (Newman 1980)

E. A moisture index $(\alpha)$ calculated as annual actual evaporation divided by annual potential evaporation (Thornthwaite and Mather 1955, 1957; Willmott and others 1985)

F. The maximum monthly value of NDVI from monthly NDVI composites for the period April 1992 to March 1993 ("maximum NDVI" as a measure of plant density) (USGS and others 1997)

G. Species richness (i.e., the number of woody species per grid point) and the number of unique species, calculated by comparing the species in each grid cell with those in the grid cell immediately to the east along the transect and summing the number of species unique to the western grid cell with the number of species unique to the eastern grid cell. H. The Jaccard similarity coefficient for each grid point and the adjacent grid point to the east

Jaccard similarity coefficient. We selected the Jaccard similarity coefficient (Jaccard 1908; Schweitzer 1994) to quantitatively compare the presence-absence data of woody plant occurrences between and among grid points. This coefficient ranges from 0 (no species in common) to 1.0 (the two assemblages being compared have exactly the same species composition). The coefficient is calculated by dividing the number of shared species between two assemblages by the sum of the number of shared species, the number of species unique to the first assemblage, and the number of species unique to the second assemblage, such that

$$
\text { Jaccard similarity coefficient }=\frac{C}{A+B+C}
$$

where $A=$ number of species unique to the first assemblage, $B=$ number of species unique to the second assemblage, and $C=$ number of shared species between the two assemblages. 


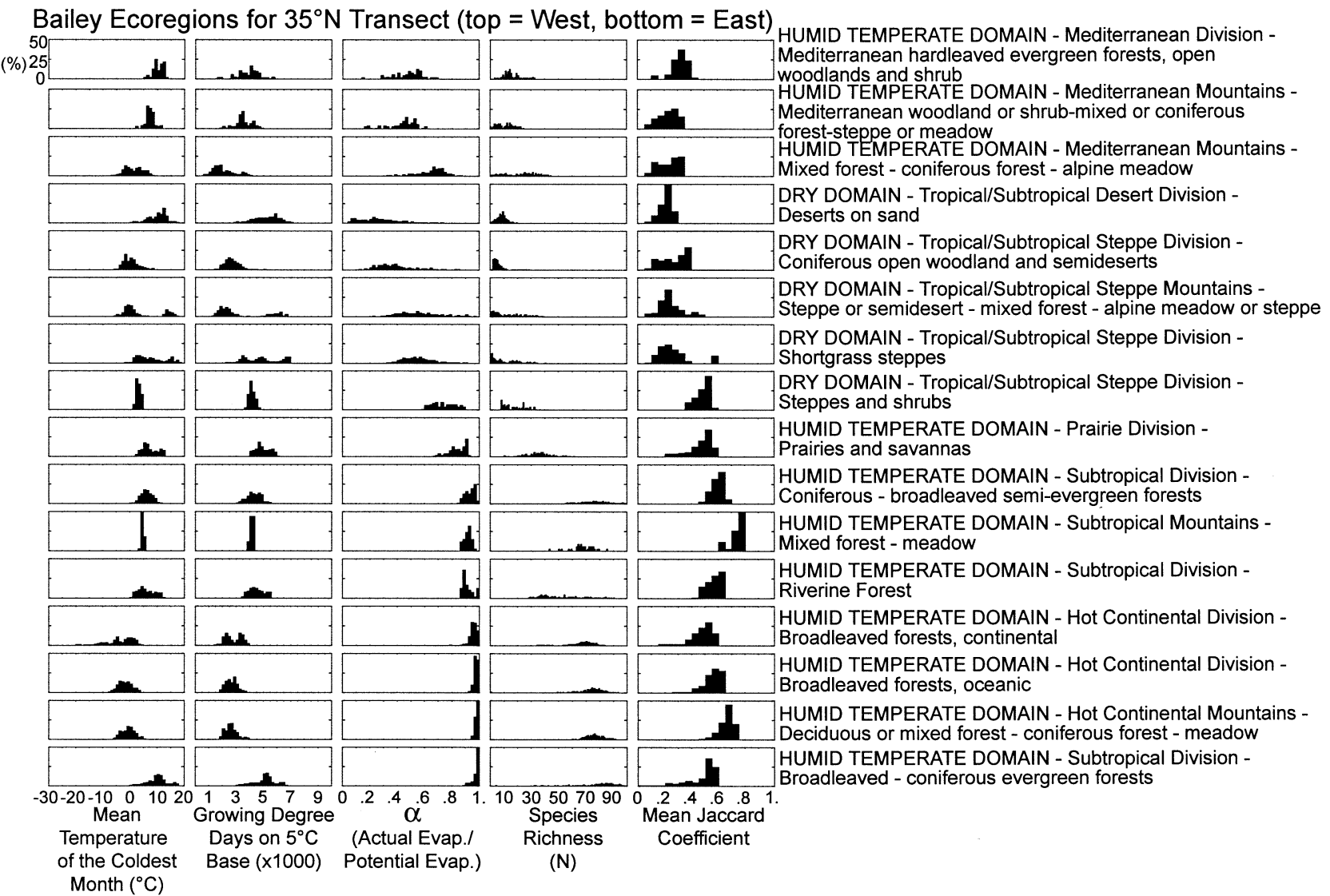

Figure 5. Histograms illustrating the degree of internal consistency of the bioclimatic, species richness, and woody flora data for Bailey ecoregions encountered on the $35^{\circ} \mathrm{N}$ transect from west to east (top to bottom). See Figure 3 for a description of the histograms.

Ecoregion boundaries. To examine the similarities and differences among the three ecoregion systems, we determined the ecoregion assignment for each $25-\mathrm{km}$ grid cell on each transect for each of the three ecoregion systems. We marked the boundaries between adjacent ecoregions with vertical lines to graphically compare the assigned boundaries between ecoregion systems (Figures 2A, 6A, and 10A). Table 1 lists the numerical designation of each ecoregion in its original published form, along with a new set of numbers that we assigned for use in this study. Under our new numerical scheme, changes between ecoregions within a broad category (such as a change from one forest type to another) are represented by small differences in numbers. Shifts from one broad category to another, such as a change from forest to grassland, are represented by larger shifts in numbers. For example, for the Küchler $35^{\circ} \mathrm{N}$ transect (Figure $2 \mathrm{~A}$ ) the reader can compare the shifts in ecoregion number and infer the back-and-forth elevation-controlled changes between the forests and grassland/desert scrub along the tran- sect from the Pacific Ocean on the left to approximately $100^{\circ} \mathrm{W}$ longitude. The ecoregion boundaries were also visually compared with the transects of elevation, bioclimatic, and floristic data to determine whether the ecoregion boundaries captured significant patterns in these environmental data.

\section{Examination of the Internal Consistency of Ecoregions}

To explore the degree of internal environmental consistency within ecoregions, we constructed histograms portraying the distributions of the bioclimatic and floristic data for every ecoregion encountered on each transect (Figures 3-5, 7-9, and 11-13). For each ecoregion, we produced histograms of the bioclimatic data (MTCO, GDD5, $\alpha$ ), species richness, and the mean Jaccard similarity coefficient. The mean Jaccard similarity coefficient histogram values are the mean of the individual Jaccard similarity coefficients calculated for the woody flora at each grid point within an ecoregion as compared with each of the other grid points 


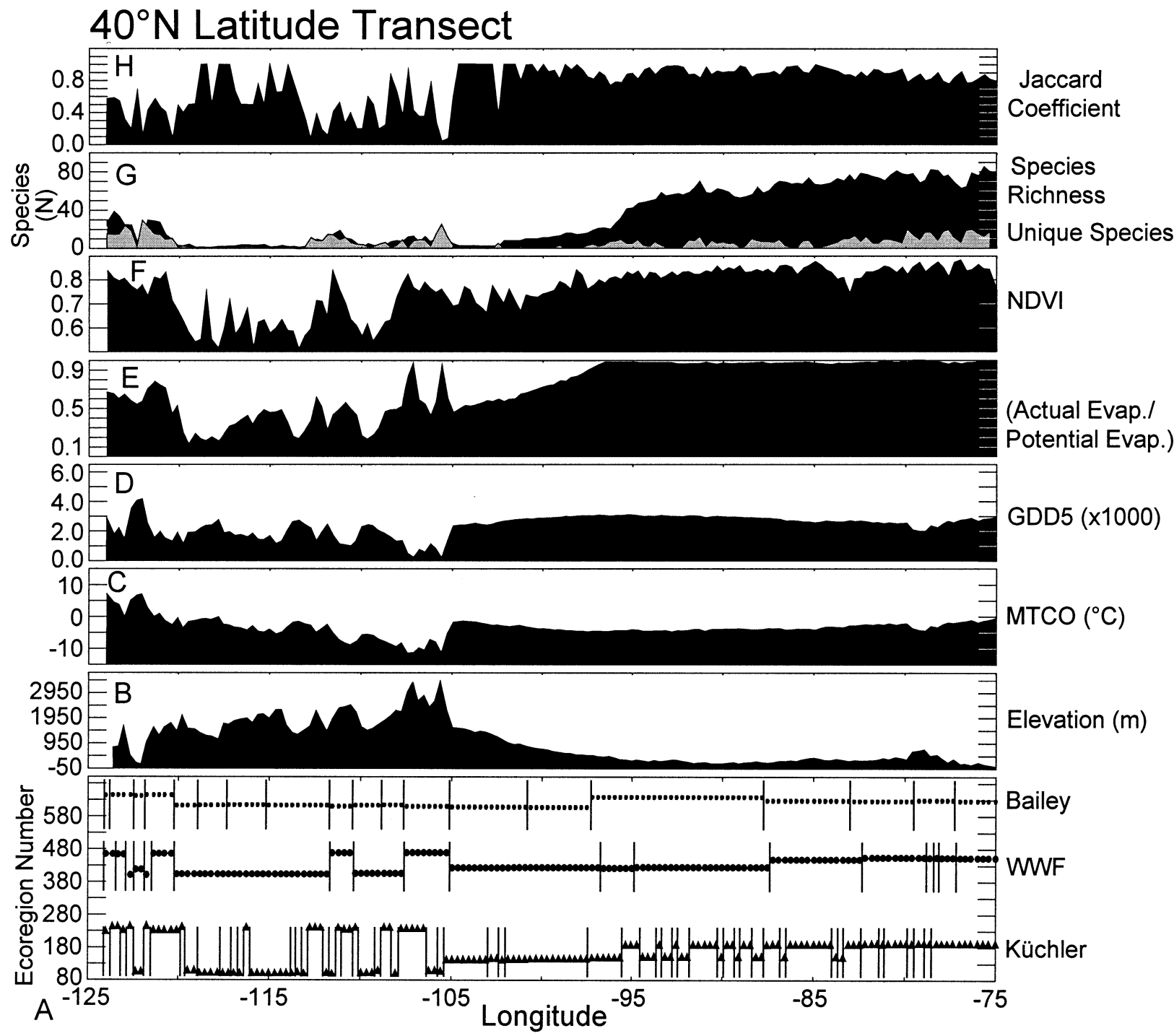

Figure 6. The $40^{\circ} \mathrm{N}$ (temperate) transect of North America showing the 25-km grid points across the continent. See Figure 2 for a description of the categories in this figure.

in the ecoregion, whether or not the other ecoregion points fall on any of the three transects. For all of the histogram plots, the height of the histogram bars $(y-$ axis) represents the percentage of the total number of points within a given ecoregion that have values that fall within the range represented by the width of each histogram column ( $x$-axis).

\section{Results}

\section{Environmental Trends}

We examined the degree to which each ecoregion system reflects topographic, bioclimatic (MTCO, GDD5, $\alpha$ ), vegetation density (NDVI), and floristic (species richness, unique species) characteristics of the land- scape along each of the three transects (Figures 2, 6, and 10). For all of the transects, the elevational data illustrate the strong contrast between the high relief and generally high elevation of the western United States compared with the lower relief and relatively lower elevation of the eastern states at the transect latitudes.

Strong topographic influences are evident in the pattern of the bioclimatic variables across North

Figure 7. Histograms illustrating the degree of internal consistency of the bioclimatic, species richness, and woody flora data for Küchler ecoregions encountered on the $40^{\circ} \mathrm{N}$ transect from west to east (top to bottom). See Figure 3 for a description of the histograms. 


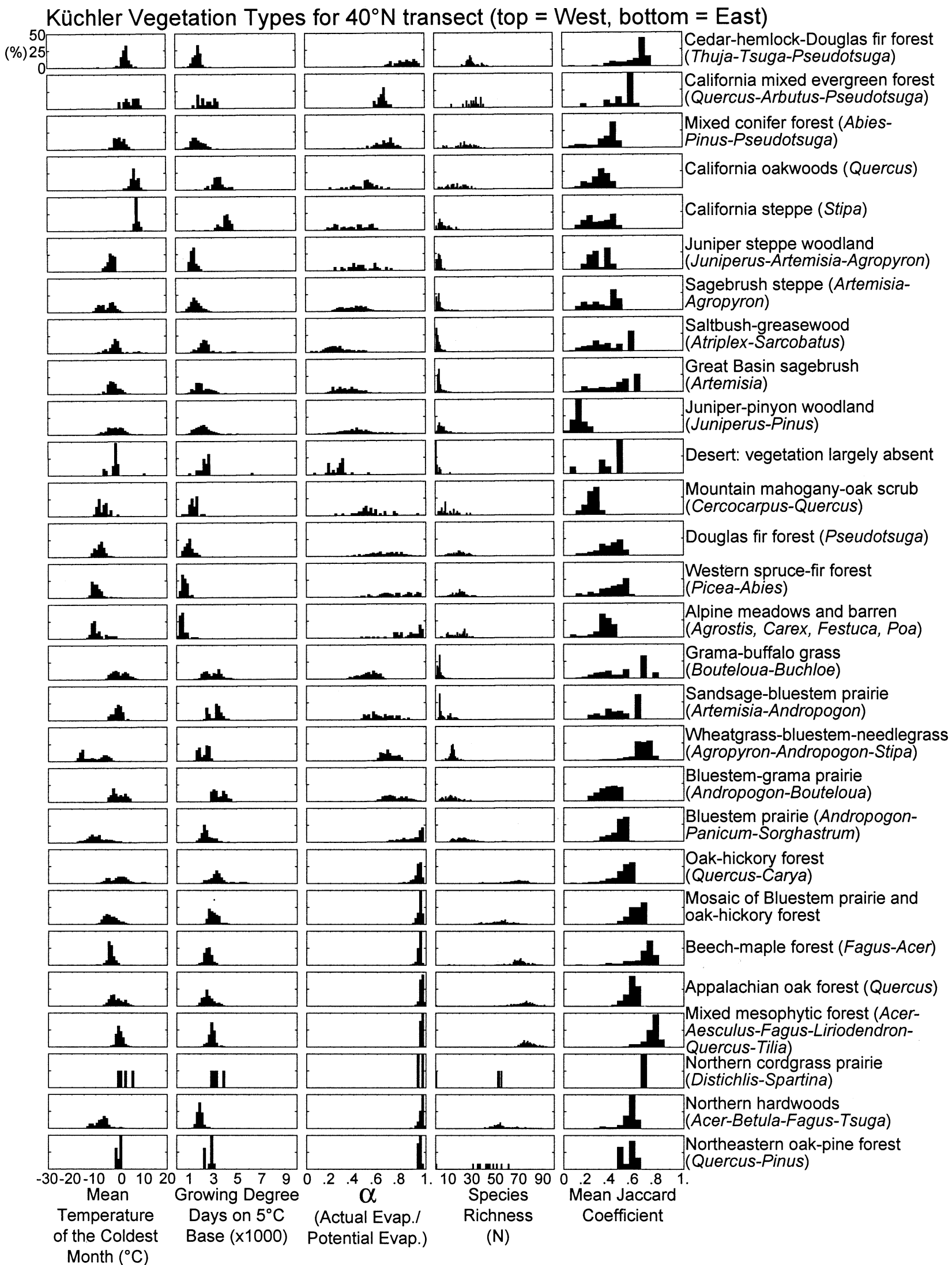




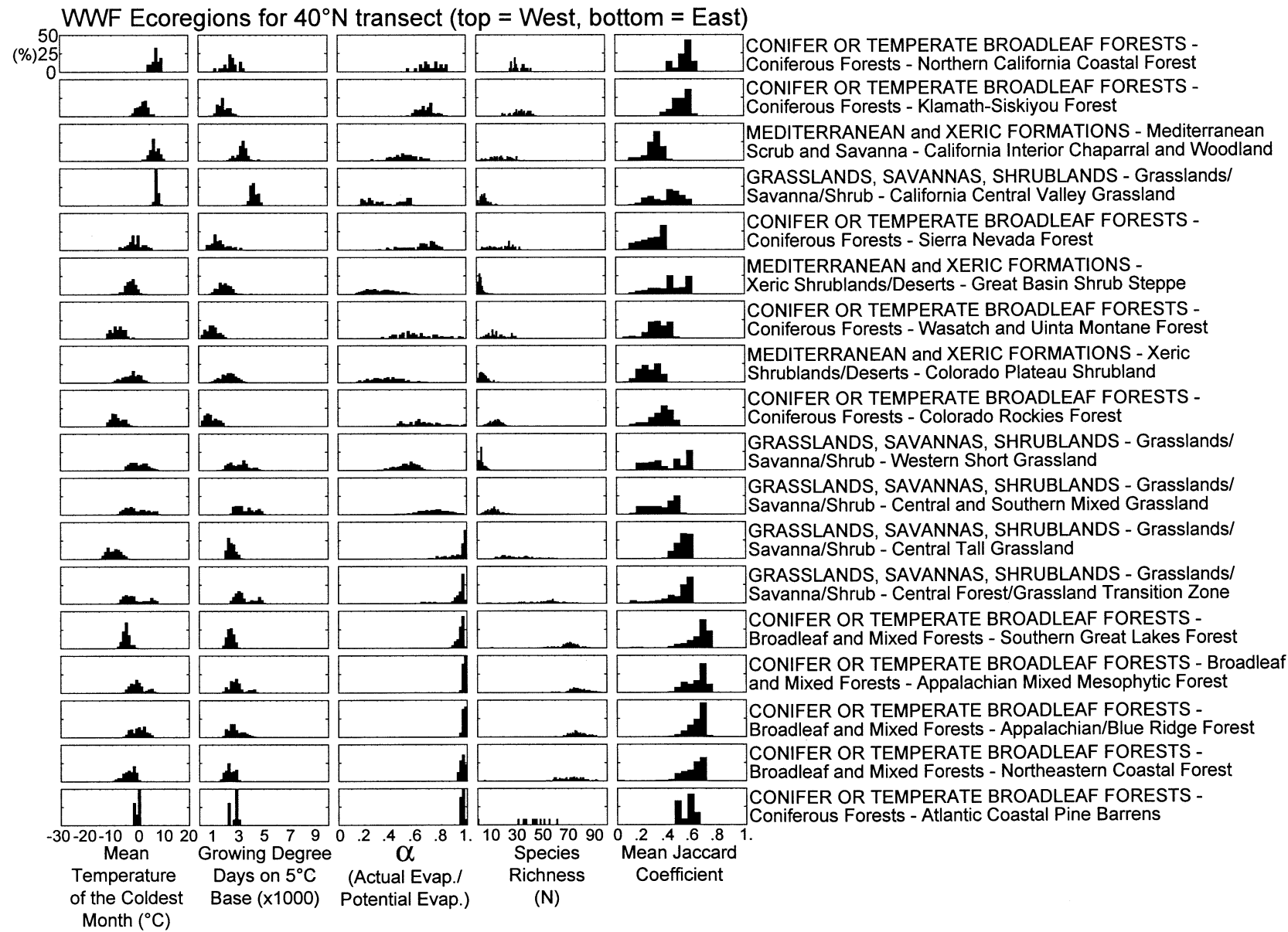

Figure 8. Histograms illustrating the degree of internal consistency of the bioclimatic, species richness, and woody flora data for WWF ecoregions encountered on the $40^{\circ} \mathrm{N}$ transect from west to east (top to bottom). See Figure 3 for a description of the histograms.

America along all of the transects. East of the Rocky Mountain front (approximately $105^{\circ} \mathrm{W}$ ) on the $35^{\circ} \mathrm{N}$ transect, MTCO remains above freezing, whereas the mountains and valleys between approximately $115^{\circ} \mathrm{W}$ and $105^{\circ} \mathrm{W}$ experience more frequent below-freezing temperatures (Figure 2C). West of $115^{\circ} \mathrm{W}$, MTCO again remains above freezing. Below-freezing winter temperatures occur across the continent at $40^{\circ} \mathrm{N}$ except in the Central Valley and coastal portions of California (Figure 6C). The winters are most severe in the Colorado Rockies and intermountain region of the western United States (Figure 6C). Along the $45^{\circ} \mathrm{N}$ transect, MTCO values are uniformly below freezing, except for a narrow band along the Pacific Coast (Figure 10C).

GDD5 is also influenced by topography with higher GDD5 values generally occurring at lower elevations. GDD5 values on the $35^{\circ} \mathrm{N}$ transect are relatively high in the deserts west of $115^{\circ} \mathrm{W}$ (Figure 2D), lower in the
Rocky Mountains, and then higher east of the Rocky Mountain front. Along both the $40^{\circ} \mathrm{N}$ and $45^{\circ} \mathrm{N}$ transects, relatively high values of GDD5 across the Great Plains reflect the hot summers that occur in this region (Figures 6D and 10D).

The moisture index is uniformly high east of approximately $100^{\circ} \mathrm{W}$ along all three of the transects (Figures 2E, 6E, and 10E). West of this longitude, only the high mountains and coastal regions have relatively high moisture indices on the transects. There is a distinct contrast in the data between the largely west-east pattern of moisture, and the north-south pattern of temperature (see Figure 1 for a continental-scale perspective).

The NDVI values (Figures 2F, 6F, and 10F) represent vegetation density along the transects, which largely reflects continental patterns of moisture availability: Vegetation density is generally low west of 


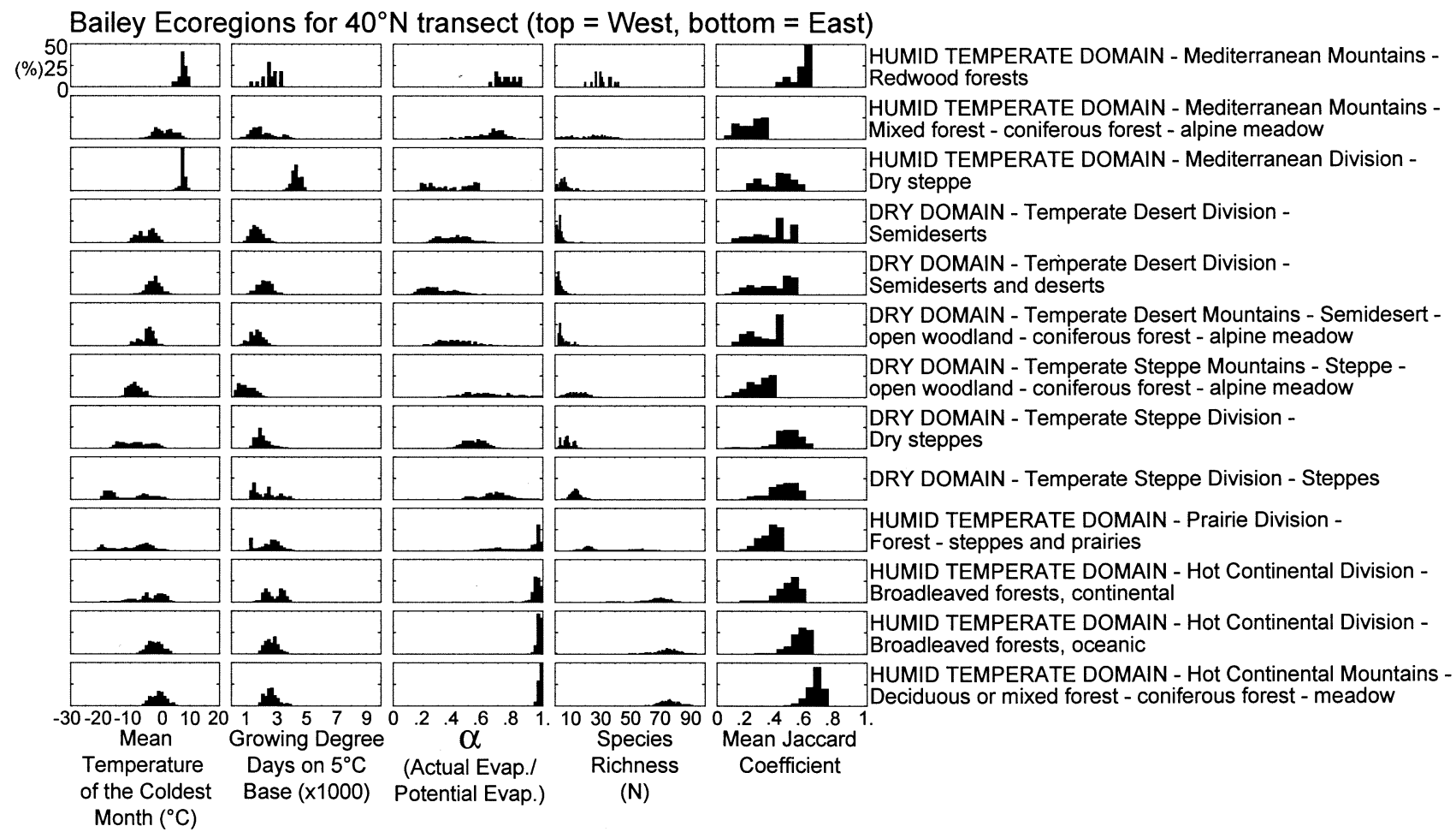

Figure 9. Histograms illustrating the degree of internal consistency of the bioclimatic, species richness, and woody flora data for Bailey ecoregions encountered on the $40^{\circ} \mathrm{N}$ transect from west to east (top to bottom). See Figure 3 for a description of the histograms.

$100^{\circ} \mathrm{W}$ and uniformly high east of that longitude. The west-east contrast in maximum NDVI values (Figure $6 \mathrm{~F}$ ) closely follows the pattern of moisture availability, with lower values in the West (except where higher values occur in the relatively moist western montane and coastal environments) and sustained high values across the East. The $45^{\circ} \mathrm{N}$ transect has higher values of NDVI in the West than do the other two transects (Figure 10F).

There is also a strong relationship between moisture availability (Figures 2E, 6E, and 10E) and species richness (Figures 2G, 6G, and 10G). East of $100^{\circ} \mathrm{W}$, the number of woody species per transect grid point increases from west to east as moisture increases, and it is uniformly above 40 species east of approximately $95^{\circ} \mathrm{W}$ on the $35^{\circ} \mathrm{N}$ and $40^{\circ} \mathrm{N}$ transects (Figures $2 \mathrm{G}$ and $6 \mathrm{G}$ ). Lower species richness values in the East on the $45^{\circ} \mathrm{N}$ transect (Figure 10G), as compared with the $40^{\circ} \mathrm{N}$ and $35^{\circ} \mathrm{N}$ transects, might be due to temperature limitations on vegetation at this latitude, whereas the somewhat higher species richness values along the western part of the $45^{\circ} \mathrm{N}$ transect (compared to the $40^{\circ} \mathrm{N}$ and $35^{\circ} \mathrm{N}$ transects) might be the result of increased moisture.
For all three transects, there is a strong contrast between the proportion of unique species between the West and the East. In the West, nearly every transect point has a large proportion of unique species (compared with its neighbors); whereas in the East, the proportion of unique species is low relative to species richness, with the exception of the changes in flora on the sediments of the Mississippi River floodplain (approximately $90^{\circ} \mathrm{W}$ on the $35^{\circ} \mathrm{N}$ transect), which are probably edaphically controlled.

The pattern of similarity measured by the Jaccard similarity coefficient (Figures $2 \mathrm{H}, 6 \mathrm{H}$, and $10 \mathrm{H}$ ) shows a strong west-east contrast. West of $100^{\circ} \mathrm{W}$, there are apparently major changes in woody flora over short distances, as the transect crosses mountains, valleys, and plains. In contrast, east of that longitude, adjacent transect grid points have very similar woody floras. The point-to-point Jaccard similarity coefficient analyses are uniformly high from the Rocky Mountains eastward to the Atlantic Coast, suggesting gradual shifts in floristic composition across this span. The generally low Jaccard similarity coefficients in the western United States indicate much greater floristic change over short distances along the transects, which is expected in areas of 


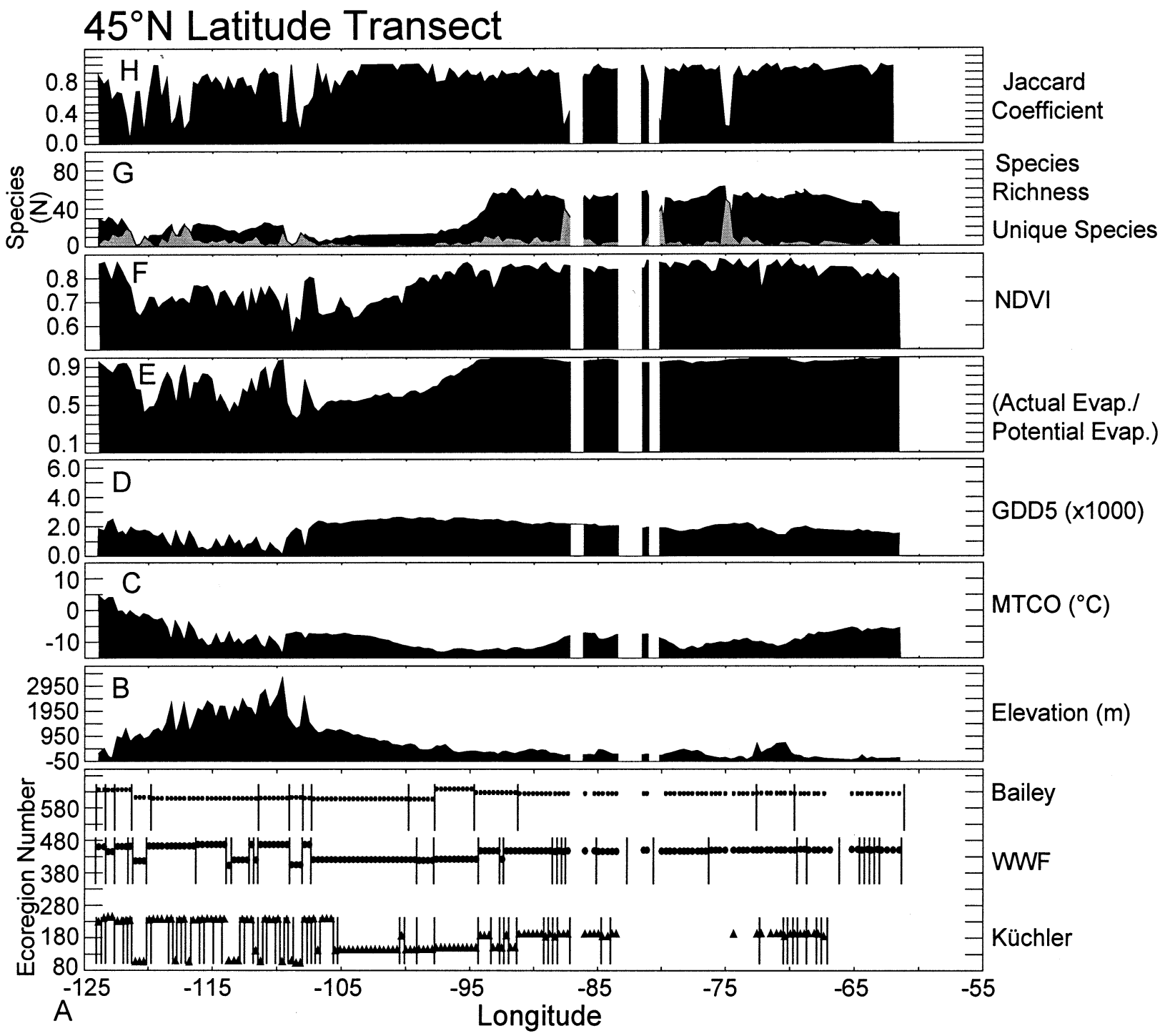

Figure 10. The $45^{\circ} \mathrm{N}$ (temperate/subboreal) transect of North America showing the 25-km grid points across the continent. See Figure 2 for a description of the categories in this figure. The white gaps in the data between $90^{\circ} \mathrm{W}$ and $80^{\circ} \mathrm{W}$ indicate where the transect crosses the Great Lakes. The Küchler ecoregions (panel A) have additional gaps where the transect crosses into Canada, which was not included in the Küchler classification system.

high relief. However, the low number of species at these western grid points also is affecting the Jaccard similarity coefficient values.

\section{Ecoregion Boundaries Compared with Environmental and Floristic Changes}

As illustrated in Figure 2A, the Küchler system has many more divisions than either of the other two ecoregion classification systems, especially in the western United States. The Küchler system reflects relatively small-scale differences in topography and climate along each transect. For example, the spatial resolution of the Küchler system is such that it registers the complex back-and-forth oscillation of the prairie-forest border near $95^{\circ} \mathrm{W}$ (Figure 2A). Conversely, the Küchler system treats the complexity of the Appalachian region's topography, climate, and vegetation with a broad-brush approach. In the western United States

Figure 11. Histograms illustrating the degree of internal consistency of the bioclimatic, species richness, and woody flora data for Küchler ecoregions encountered on the $45^{\circ} \mathrm{N}$ transect from west to east (top to bottom). See Figure 3 for a description of the histograms. 


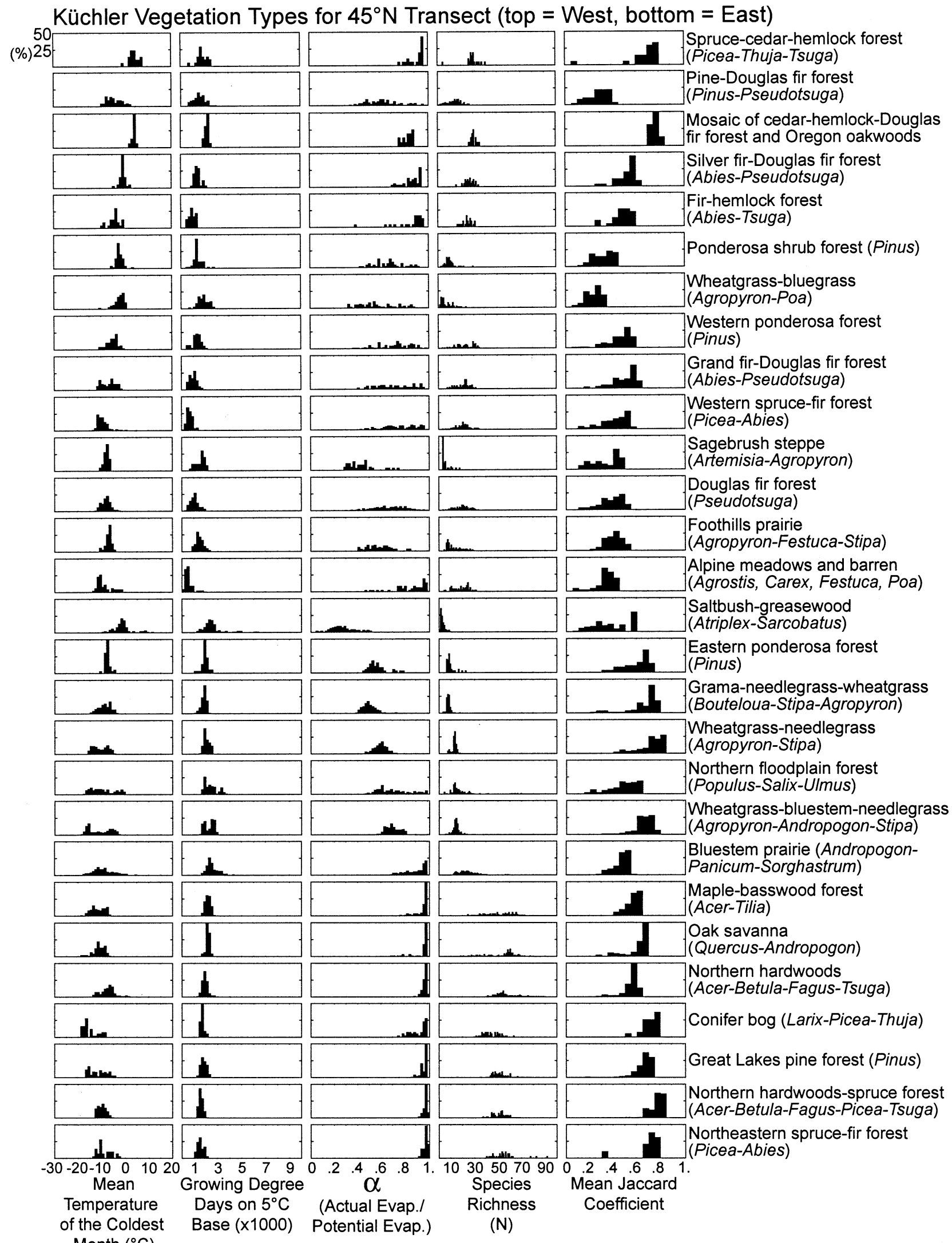




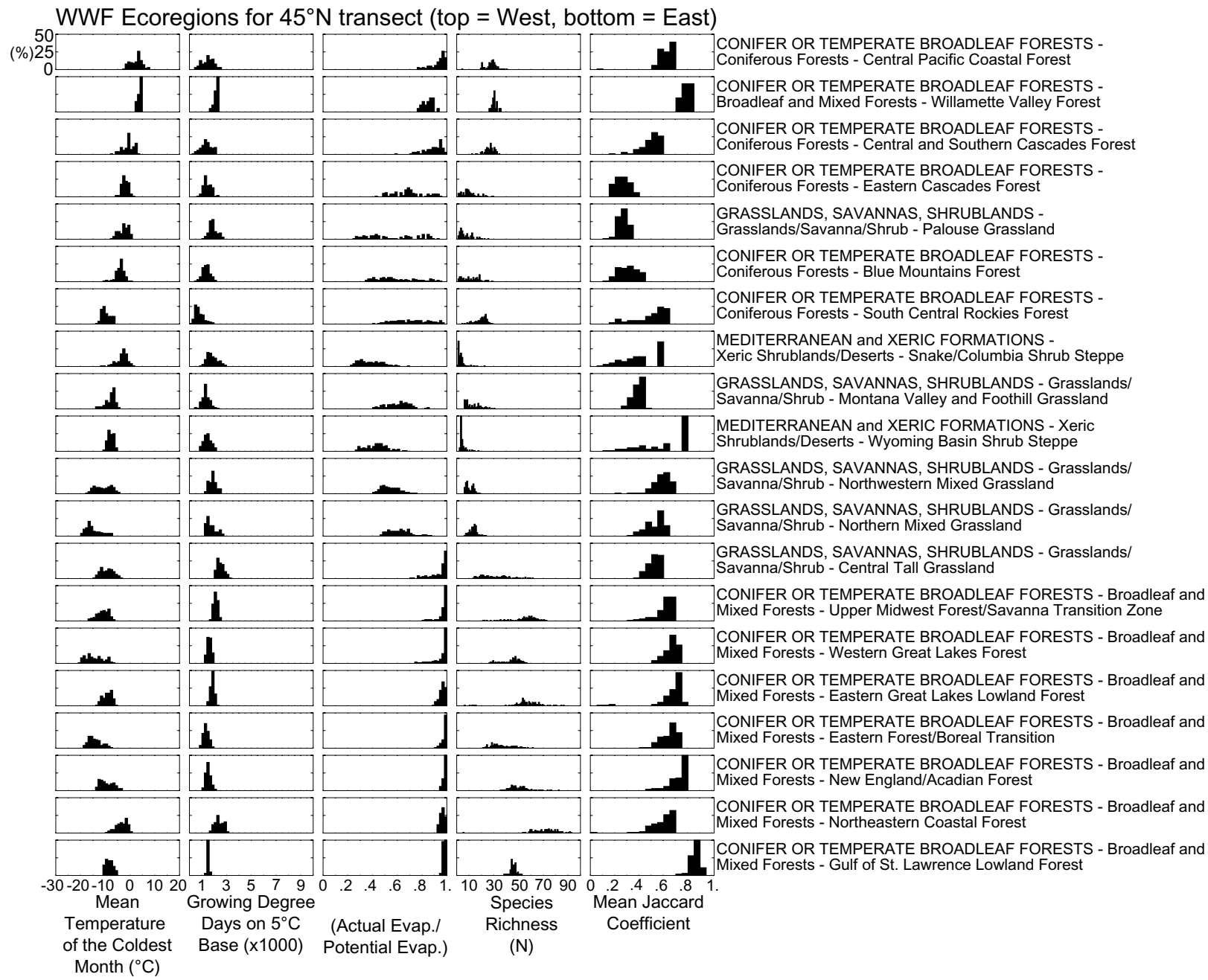

Figure 12. Histograms illustrating the degree of internal consistency of the bioclimatic, species richness, and woody flora data for WWF ecoregions encountered on the $45^{\circ} \mathrm{N}$ transect from west to east (top to bottom). See Figure 3 for a description of the histograms.

along the $40^{\circ} \mathrm{N}$ transect (Figures $6 \mathrm{~A}$ ), the Küchler boundaries align well with environmental and floristic changes in the transect data. Particularly prominent is the sharp break in environmental conditions and Jaccard similarity coefficients at the Rocky Mountain front in Colorado(approximately $105^{\circ} \mathrm{W}$ ). Küchler, WWF, and Bailey ecoregion systems all reflect large changes at this location.

The WWF ecoregion system has many fewer divisions than the Küchler system on all three transects, particularly in the western United States, where major areas of desert-grassland-steppe are treated as single units on the $35^{\circ} \mathrm{N}$ transect (Figure 2A). Many of the Basin-and-Range changes in the West registered in the Küchler system are also grouped into a single division under the WWF system on the $40^{\circ} \mathrm{N}$ transect (Fig- ure 6A). The WWF system treats the forest-prairie transition region at $95^{\circ} \mathrm{W}$ as a single unit on the $40^{\circ} \mathrm{N}$ and $45^{\circ} \mathrm{N}$ transects and also provides a relatively simple portrayal of the Appalachian region, albeit with boundaries offset from those of Küchler (Figures 6A and 10A). Major changes in bioclimatic variables align with WWF boundaries, especially in the western United States. Changes in the number of unique species and species richness also register well in the WWF ecoregion boundaries along the $35^{\circ} \mathrm{N}$ transect (Figure 2G) Along the $40^{\circ} \mathrm{N}$ and $45^{\circ} \mathrm{N}$ transects, some of these ecoregion divisions correspond with low Jaccard similarity coefficient values (Figures $6 \mathrm{H}$ and $10 \mathrm{H}$ ), although many others do not.

The Bailey ecoregion system has fewer divisions than the other two systems in the western United States 


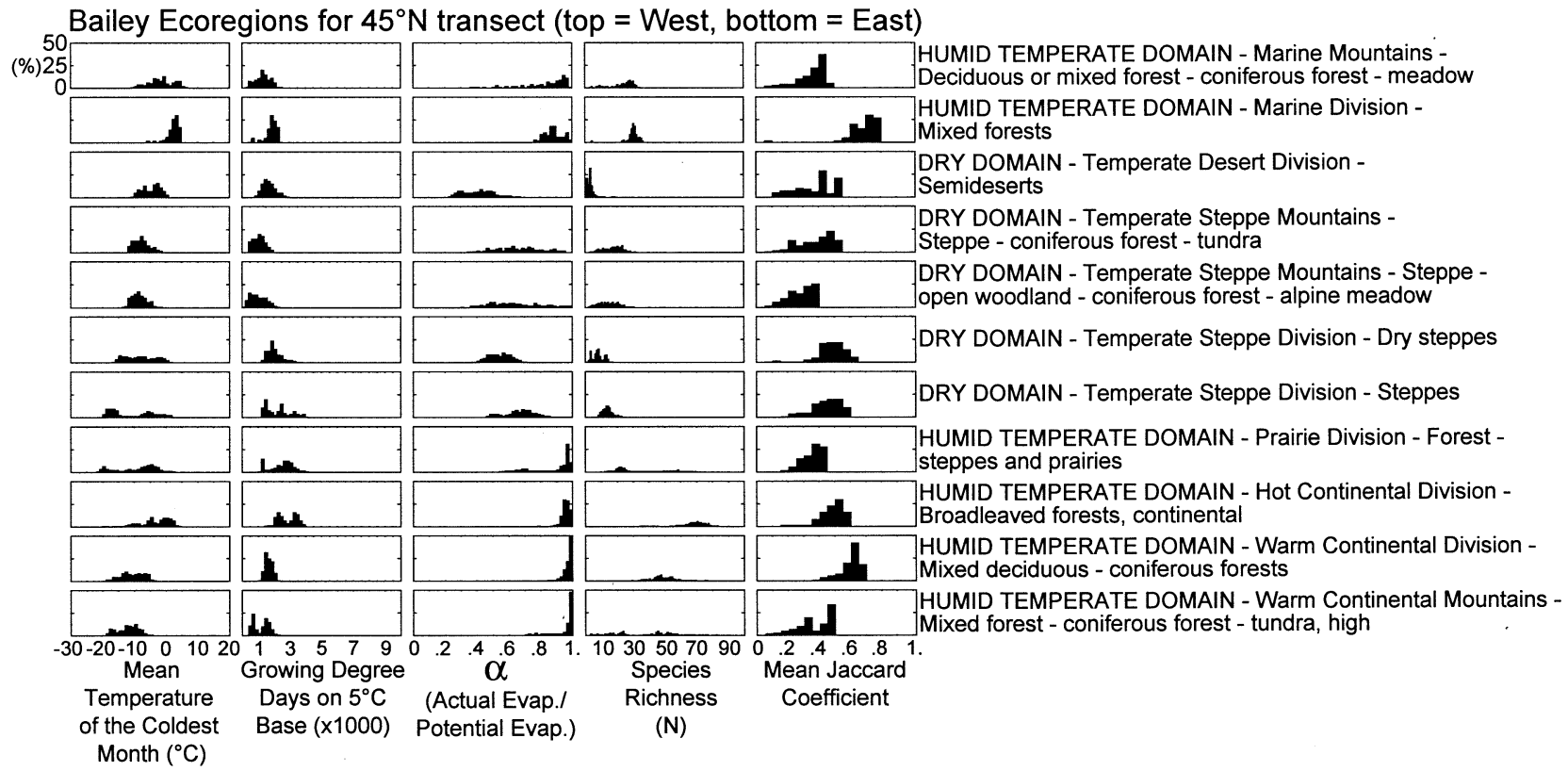

Figure 13. Histograms illustrating the degree of internal consistency of the bioclimatic, species richness, and woody flora data for Bailey ecoregions encountered on the $45^{\circ} \mathrm{N}$ transect from west to east (top to bottom). See Figure 3 for a description of the histograms.

along the $35^{\circ} \mathrm{N}$ transect, but it has more divisions than the WWF system in the eastern United States (Figure 2A). The Bailey system has nearly the same number of ecoregions as the WWF system on the $40^{\circ} \mathrm{N}$ transect (Figure 6A). However, the Bailey system has more divisions in the western United States than the WWF system, and fewer in the eastern United States. The Bailey system boundaries generally occur near breaks in climate, topography, NDVI, or species richness along the $35^{\circ} \mathrm{N}$ transect (Figure 2). The boundaries in the Appalachian region appear particularly well placed in comparison with our data. The boundaries between Bailey ecoregions in the West along the $40^{\circ} \mathrm{N}$ transect align well with changes in topography, NDVI, and Jaccard coefficients (Figure 6). The boundaries between Bailey ecoregions in the East on the $40^{\circ} \mathrm{N}$ transect are less well aligned with environmental or floristic changes in our datasets. Along the $45^{\circ} \mathrm{N}$ transect, the Bailey system has the fewest ecoregion divisions of the three systems, with individual ecoregions covering broad areas of the Pacific Northwest and eastern United States (Figure 10).

\section{Internal Consistency of Ecoregions}

Figures 3-5, 7-9, and 11-13 illustrate the bioclimatic, species richness, and mean Jaccard similarity coefficients for each ecoregion encountered along each of the three transects. For the bioclimatic and species richness vari- ables, if an ecoregion is strongly internally consistent in regard to a specific variable, then the histograms should have a unimodal distribution with a relatively narrow range of variability around the mode. Strong internal consistency for the Jaccard similarity coefficient should be represented by the mean within-ecoregion Jaccard coefficients approaching the value of 1.0.

For the Küchler $35^{\circ} \mathrm{N}$ transect, the seven easternmost ecoregions (the bottom seven on Figure 3) meet most of the criteria for a high degree of internal consistency. The bioclimatic variables, particularly $\alpha$, tend to have unimodal distributions. The Jaccard coefficients approach 0.8 for two of these seven ecoregions and are above 0.5 for nearly all of the seven. Westward, the picture is different: In the arid and semiarid ecoregions, the spread of bioclimatic variables is generally greater, there are more bimodal or multimodal distributions, species richness is generally low, and the within-ecoregion Jaccard coefficients are significantly lower.

On the $40^{\circ} \mathrm{N}$ transect, the MTCO and GDD5 bioclimatic variables for the Küchler ecoregions generally have fairly narrow ranges (Figure 7), but some variable distributions exhibit bimodal or multimodal characteristics, which might suggest a mixture of different environmental conditions within these ecoregions. The moisture index for Küchler ecoregions on the $40^{\circ} \mathrm{N}$ transect is consistently high in the eastern United 
Table 1. Ecoregions used in this study from the Küchler, WWF, and Bailey ecoregion classification systems, the new numbers assigned to the ecoregions, and the corresponding ecoregion numbers from the original publications

\section{Code}

used in this

Original

publication

code

Bailey Ecoregions (Bailey 1997)

Humid Temperate Domain

Mediterranean Mountains - Mediterranean woodland

or shrub-mixed or coniferous forest - steppe or meadow

Mediterranean Mountains - Mixed forest - coniferous

forest - alpine meadow

Mediterranean Division - Redwood forests

Mediterranean Division - Mediterranean hardleaved evergreen forests, open woodlands and shrub

Mediterranean Division - Dry steppe

Prairie Division - Prairies and savannas

Prairie Division - Forest-steppes and prairies

Marine Mountains - Deciduous or mixed

forest - coniferous forest - meadow

Marine Division - Mixed forests

Subtropical Mountains - Mixed forest - meadow

Subtropical Division - Riverine forest

Subtropical Division - Coniferous-broadleaved semievergreen forests

Subtropical Division - Broadleaved-coniferous evergreen forests

Hot Continental Mountains - Deciduous or mixed forest - coniferous forest - meadow

Hot Continental Division - Broadleaved forests, continental

Hot Continental Division - Broadleaved forests, oceanic

Warm Continental Mountains - Mixed forest - coniferous forest - tundra, high

Warm Continental Division - Mixed deciduous-coniferous forests

Dry Domain

Temperate Desert Mountains - Semidesert - open

woodland - coniferous forest - alpine meadow

Temperate Desert Division - Semideserts and deserts

Temperate Desert Division - Semideserts

Temperate Steppe Mountains - Steppe - open woodland - coniferous forest - alpine meadow

Temperate Steppe Mountains - Steppe - coniferous forest - tundra

Temperate Steppe Division — Dry steppes

Temperate Steppe Division - Steppes

Tropical/Subtropical Desert Division — Deserts on sand

Tropical/Subtropical Steppe Mountains - Steppe or semidesert - mixed forest - alpine meadow or steppe

Tropical/Subtropical Steppe Division - Shortgrass steppes

Tropical/Subtropical Steppe Division - Steppes and shrubs

Tropical/Subtropical Steppe Division - Coniferous 
Table 1. Continued.

Code

used in this

publication

Original

code

World Wildlife Fund Ecoregions (Ricketts and others 1999a)

Conifer or Temperate Broadleaf Forests

Coniferous Forests - Middle Atlantic Coastal Forest

Coniferous Forests - Atlantic Coastal Pine Barrens 471

Coniferous Forests - Arizona Mountains Forest

Coniferous Forests - Colorado Rockies Forest

Coniferous Forests - Wasatch and Uinta Montane Forest

Coniferous Forests - South Central Rockies Forest

Coniferous Forests - Sierra-evada Forest

Coniferous Forests - Northern California Coastal Forest

Coniferous Forests - Klamath-Siskiyou Forest

Coniferous Forests - Blue Mountains Forest

Coniferous Forests - Eastern Cascades Forest

Coniferous Forests - Central and Southern Cascades Forest

Coniferous Forests - Central Pacific Coastal Forest

Broadleaf and Mixed Forests - Southeastern Mixed Forest

Broadleaf and Mixed Forests - Mississippi Lowland Forest

Broadleaf and Mixed Forests - Ozark Mountain Forest

Broadleaf and Mixed Forests - Central U.S. Hardwood Forest

Broadleaf and Mixed Forests - Appalachian Mixed

Mesophytic Forest

Broadleaf and Mixed Forests - Appalachian/Blue

Ridge Forest

Broadleaf and Mixed Forests - Northeastern

Coastal Forest

Broadleaf and Mixed Forests - Gulf of St. Lawrence

Lowland Forest

Broadleaf and Mixed Forests - New England/Acadian Forest

471

470

469

468

467

466

465

464

463

462

461

460

459

458

457

456

455

454

453

Broadleaf and Mixed Forests - Eastern

Great Lakes Lowland Forest

Broadleaf and Mixed Forests - Southern

Great Lakes Forest

Broadleaf and Mixed Forests - Upper

Midwest Forest/Savanna Transition Zone

Broadleaf and Mixed Forests - Eastern

Forest/Boreal Transition

Broadleaf and Mixed Forests - Western

Great Lakes Forest

Broadleaf and Mixed Forests - Willamette Valley Forest

Grasslands, Savannas, Shrublands

Grasslands/Savanna/Shrub - Central Forest/Grassland Transition Zone

Grasslands/Savanna/Shrub - Central and Southern Mixed Grassland

Grasslands/Savanna/Shrub - Western

Short Grassland

Grasslands/Savanna/Shrub - Central Tall Grassland

Grasslands/Savanna/Shrub - Northwestern

Mixed Grassland

Grasslands/Savanna/Shrub - Montana Valley and

Foothill Grassland

Grasslands/Savanna/Shrub - Northern Mixed Grassland

Grasslands/Savanna/Shrub - California Central Valley Grassland

Grasslands/Savanna/Shrub - Palouse Grassland

Mediterranean and Xeric Formations

Xeric Shrublands/Deserts - Mojave Desert

407 
Table 1. Continued.

\begin{tabular}{|c|c|c|}
\hline & $\begin{array}{l}\text { Code } \\
\text { used in this } \\
\text { publication }\end{array}$ & $\begin{array}{l}\text { Original } \\
\text { code }\end{array}$ \\
\hline Xeric Shrublands/Deserts — Colorado Plateau Shrubland & 406 & 78 \\
\hline Xeric Shrublands/Deserts - Wyoming Basin Shrub Steppe & 405 & 77 \\
\hline Xeric Shrublands/Deserts — Great Basin Shrub Steppe & 404 & 76 \\
\hline Xeric Shrublands/Deserts - Snake/Columbia Shrub Steppe & 403 & 75 \\
\hline $\begin{array}{l}\text { Mediterranean Scrub and Savanna - California Montane } \\
\text { Chaparral and Woodland }\end{array}$ & 402 & 71 \\
\hline $\begin{array}{l}\text { Mediterranean Scrub and Savanna - California Interior } \\
\text { Chaparral and Woodland }\end{array}$ & 401 & 70 \\
\hline \multicolumn{3}{|l|}{ Küchler Ecoregions (Küchler 1966) } \\
\hline \multicolumn{3}{|l|}{ Western Forests } \\
\hline $\begin{array}{l}\text { Broadleaf and Needleleaf Forests - Transition between } \\
\text { oak-juniper woodland and mountain mahogany-oak scrub }\end{array}$ & 247 & 32 \\
\hline Broadleaf and Needleleaf Forests - California oakwoods & 246 & 30 \\
\hline $\begin{array}{l}\text { Broadleaf and Needleleaf Forests - California mixed } \\
\text { evergreen forest }\end{array}$ & 245 & 29 \\
\hline $\begin{array}{l}\text { Broadleaf and Needleleaf Forests - Mosaic of cedar- } \\
\text { hemlock-Douglas fir forest and Oregon oakwoods }\end{array}$ & 244 & 28 \\
\hline Needleleaf Forests - Juniper steppe woodland & 243 & 24 \\
\hline Needleleaf Forests - Juniper-pinyon woodland & 242 & 23 \\
\hline Needleleaf Forests - Arizona pine forest & 241 & 19 \\
\hline Needleleaf Forests — Pine-Douglas fir forest & 240 & 18 \\
\hline Needleleaf Forests - Eastern ponderosa forest & 239 & 16 \\
\hline Needleleaf Forests - Western spruce-fir forest & 238 & 15 \\
\hline Needleleaf Forests - Grand fir-Douglas fir forest & 237 & 14 \\
\hline Needleleaf Forests — Douglas fir forest & 236 & 12 \\
\hline Needleleaf Forests - Western ponderosa forest & 235 & 11 \\
\hline Needleleaf Forests - Ponderosa shrub forest & 234 & 10 \\
\hline Needleleaf Forests - Mixed conifer forest & 233 & 5 \\
\hline Needleleaf Forests —Fir-hemlock forest & 232 & 4 \\
\hline Needleleaf Forests — Silver fir-Douglas fir forest & 231 & 3 \\
\hline Needleleaf Forests - Cedar-hemlock-Douglas fir forest & 230 & 2 \\
\hline Needleleaf Forests — Spruce-cedar-hemlock forest & 229 & 1 \\
\hline $\begin{array}{l}\text { Shrub and Grassland Combinations - Grama-tobosa } \\
\text { shrubsteppe }\end{array}$ & 111 & 58 \\
\hline Shrub and Grassland Combinations - Sagebrush steppe & 110 & 55 \\
\hline Grassland — Grama-galleta steppe & 109 & 53 \\
\hline Grassland - Alpine meadows and barren & 108 & 52 \\
\hline Grassland - Wheat grass-blue grass & 107 & 51 \\
\hline Grassland — California steppe & 106 & 48 \\
\hline Shrub - Chaparral & 248 & 33 \\
\hline Shrub - Desert: vegetation largely absent & 105 & 46 \\
\hline Shrub - Creosote bush & 104 & 41 \\
\hline Shrub - Saltbush-greasewood & 103 & 40 \\
\hline Shrub - Great Basin sagebrush & 102 & 38 \\
\hline Shrub - Mountain mahogany-oak scrub & 101 & 37 \\
\hline \multicolumn{3}{|l|}{ Central and Eastern Grasslands } \\
\hline $\begin{array}{l}\text { Grassland and Forest Combinations - Mesquite- } \\
\text { buffalo grass }\end{array}$ & 154 & 85 \\
\hline Grassland and Forest Combinations - Cross timbers & 153 & 84 \\
\hline $\begin{array}{l}\text { Grassland and Forest Combinations - Mosaic of } \\
\text { Bluestem prairie and oak-hickory forest }\end{array}$ & 152 & 82 \\
\hline Grassland and Forest Combinations - Oak savanna & 151 & 81 \\
\hline Grassland — Bluestem prairie & 150 & 74 \\
\hline Grassland - Northern cordgrass prairie & 149 & 73 \\
\hline Grassland - Shinnery & 148 & 71 \\
\hline Grassland — Sandsage-bluestem prairie & 147 & 70 \\
\hline Grassland — Bluestem-grama prairie & 146 & $\begin{array}{c}69 \\
\text { (Continued) }\end{array}$ \\
\hline
\end{tabular}


Table 1. Continued.

\begin{tabular}{|c|c|c|}
\hline & $\begin{array}{l}\text { Code } \\
\text { used in this } \\
\text { publication }\end{array}$ & $\begin{array}{l}\text { Original } \\
\text { code }\end{array}$ \\
\hline Grassland - Wheatgrass-bluestem-needlegrass & 145 & 67 \\
\hline Grassland - Wheatgrass-needlegrass & 144 & 66 \\
\hline Grassland — Grama-buffalo grass & 143 & 65 \\
\hline Grassland - Grama-needlegrass-wheatgrass & 142 & 64 \\
\hline Grassland —Foothills prairie & 141 & 63 \\
\hline \multicolumn{3}{|l|}{ Eastern Forests } \\
\hline Broadleaf and Needleleaf Forests - Pocosin & 199 & 114 \\
\hline $\begin{array}{l}\text { Broadleaf and Needleleaf Forests - Southern } \\
\text { flood plain forest }\end{array}$ & 198 & 113 \\
\hline Broadleaf and Needleleaf Forests - Southern mixed forest & 197 & 112 \\
\hline $\begin{array}{l}\text { Broadleaf and Needleleaf Forests - Oak-hickory- } \\
\text { pine forest }\end{array}$ & 196 & 111 \\
\hline $\begin{array}{l}\text { Broadleaf and Needleleaf Forests - Northeastern } \\
\text { oak-pine forest }\end{array}$ & 195 & 110 \\
\hline $\begin{array}{l}\text { Broadleaf and Needleleaf Forests - Northern hardwoods- } \\
\text { spruce forest }\end{array}$ & 194 & 108 \\
\hline $\begin{array}{l}\text { Broadleaf and Needleleaf Forests - Northern } \\
\text { hardwoods }\end{array}$ & 193 & 106 \\
\hline Broadleaf Forests - Appalachian oak forest & 192 & 104 \\
\hline Broadleaf Forests - Mixed mesophytic forest & 191 & 103 \\
\hline Broadleaf Forests - Beech-maple forest & 190 & 102 \\
\hline Broadleaf Forests - Oak-hickory forest & 189 & 100 \\
\hline Broadleaf Forests - Maple-basswood forest & 188 & 99 \\
\hline Broadleaf Forests - Northern floodplain forest & 187 & 98 \\
\hline Needleleaf Forests - Northeastern spruce-fir forest & 186 & 96 \\
\hline Needleleaf Forests — Great Lakes pine forest & 185 & 95 \\
\hline Needleleaf Forests — Conifer bog & 184 & 94 \\
\hline
\end{tabular}

States, drops on the Great Plains, rises in the Colorado Rocky Mountains, drops in the intermountain region, and then rises again near the Pacific Ocean. The widths of the histograms for this variable are greater in dry climates than in humid climates, and multimodal distributions occur under the dry climates. Species richness and mean Jaccard coefficients are higher in the areas of moist climates along this transect, although both variables decline toward the East Coast.

The Küchler ecoregions along the $45^{\circ} \mathrm{N}$ transect tend to produce the most narrow histograms of the three systems, particularly with regard to MTCO and GDD5 (Figure 11), indicating a fairly high degree of internal consistency within the ecoregions for these variables. The moisture index, $\alpha$, tends to be well constrained for ecoregions in wetter portions of the $45^{\circ} \mathrm{N}$ transect (the East and Pacific Northwest) and less well constrained along drier portions of the transect. The pattern of species richness values, in general, follows the pattern of the moisture index, with higher species richness in areas with a high moisture index and low species richness in areas with a low moisture index. Jaccard values for Küchler ecoregions also tend to vary with moisture, although temperature might play an increasingly important role at this latitude.

The internal consistency results for the WWF $35^{\circ} \mathrm{N}$ transect are similar to those for the Küchler $35^{\circ} \mathrm{N}$ transect-eastern forested ecoregions are more internally consistent in regard to bioclimatic and species richness variables and have higher Jaccard coefficients (Figure 4). Also similar to the Küchler system, the WWF ecoregions on the $40^{\circ} \mathrm{N}$ and $45^{\circ} \mathrm{N}$ transects (Figures 8 and 12) generally have well constrained, unimodal distributions for MTCO and GDD5. The $\alpha$ histograms are also well constrained along the eastern, wetter portions of the transect, but less well constrained along the drier portions. Species richness under the WWF system, as with the Küchler system, shows a strong relation with moisture conditions. The Jaccard similarity coefficient analyses show relatively coherent ecoregions in the moist climates of the eastern United States and far western United States. Conversely, these analyses suggest less coherent ecoregions under arid climates (based on the few woody plant taxa that occur in these ecoregions). 
The Bailey $35^{\circ} \mathrm{N}$ ecoregion histograms are depicted in Figure 5, and again the overall pattern is similar to that of the Küchler and WWF results. However, the Bailey system has generally lower Jaccard coefficients for the ecoregions of the eastern forests than do the WWF ecoregions along this transect, suggesting a somewhat lower degree of internal consistency (perhaps reflecting greater lumping of diverse physiographic and climatic environments into single ecoregions in this complex environment). The Bailey ecoregion system on the $40^{\circ} \mathrm{N}$ transect has the fewest ecoregions of the three systems under consideration (Figure 9). The MTCO and GDD5 distributions for this transect are relatively tightly grouped but include some bimodal and multimodal groups. The patterns for the moisture index and species richness are similar to those for the other two ecoregion systems. The mean Jaccard similarity coefficient analyses indicate relatively coherent ecoregions (floristically) near the east coast, with lower mean coefficients (and presumably less internally consistent ecoregions) occurring in the dry climate of the western United States. Unlike with the other two ecoregion classification systems along this transect, the Jaccard similarity coefficient analyses do not show internally consistent (floristically) Bailey ecoregions under the moist climates near the West Coast. This suggests that the Bailey system of fewer and broader ecoregions merges several relatively distinct floristic associations that appear in the other two systems. The Bailey ecoregion histograms of the bioclimatic variables on the $45^{\circ} \mathrm{N}$ transect (Figure 13) differ from the Küchler and WWF histograms in that they tend to be bimodal or multimodal, with each ecoregion covering a broad range of values. The species richness histograms are also much broader, and the Jaccard values tend to be low, with the exception of one ecoregion division near the West Coast.

\section{Discussion}

The three latitudinal transects analyzed in this study describe the general environmental variations across the continent. MTCO and GDD5 are generally higher at lower latitudes. Moisture availability $(\alpha)$ varies more with longitude than latitude, but points along the $45^{\circ} \mathrm{N}$ transect have consistently higher moisture index levels than points at similar longitudes on the two transects further to the south. Species richness is highest on the southernmost transect and lowest on the northernmost transect and appears to be strongly tied to moisture availability on the $35^{\circ} \mathrm{N}$ and $40^{\circ} \mathrm{N}$ transects, although this relationship is somewhat mediated by temperature for the $45^{\circ} \mathrm{N}$ transect. Transect grid points in arid environments consistently have relatively low species richness and low point-to-point and within-ecoregion mean Jaccard coefficients. Collectively, these western dry environments also have a greater overall range of moisture conditions than do transect grid points in the humid East, probably a result of the large number of microenvironments created by the topographic complexity of the West.

When we compare the boundaries of the ecoregions from the three different classification systems considered in this study, they rarely align with one another along the transects. The Küchler ecoregion system always has the largest number of categories on each of the transects and repeats ecoregions along the transects to a greater degree. The WWF and Bailey systems frequently have similar numbers of ecoregions along each transect (although Bailey generally has fewer), but the ecoregions are frequently clustered differently, with one system having more ecoregions in the West and fewer in the East, or vice versa. In general, however, it is easier to detect relations between ecoregion boundaries and topography in the western United States than in the East for all three ecoregion systems. Unfortunately, the relatively low number of woody plant species in much of the West inhibits tracking ecoregion boundaries in this region using the species richness data. The gradual shifts in flora in the eastern United States also make it difficult to align floristic changes with ecoregion boundaries in that region. The subtle topographic, climatic, and floristic changes in the East also result in fewer correspondences between ecoregion boundaries among the three systems.

Many of these environmental patterns are picked up by one or more of the ecoregion classification systems we examined. The extent to which there is correspondence among the elevation, bioclimatic, and floristic data and the individual ecoregion classification systems might depend in large part, however, on the goals and methodologies with which each of the ecoregion systems was developed, and some of these differences are discussed below.

\section{Küchler Ecoregions}

Küchler's potential natural vegetation “ecoregions" are based on the distribution of natural plant communities. They are less bound than the Bailey and WWF classification systems to the concept of ecoregions representing broad contiguous areas of similar environments. In addition, environmental variables, such as climate, were not explicitly considered in developing the potential natural vegetation categories. Thus, we would expect the Küchler 
ecoregions to match the bioclimatic and elevation transect data only to the extent that each Küchler vegetation community reflects variations in climate and topography. From our analysis, it appears that Küchler's ecoregions display a relatively good correspondence with bioclimatic variables, particularly the moisture index $(\alpha)$. This tight correspondence may also be a result of the larger number of potential natural vegetation types in Küchler's classification scheme, allowing more specific environmental relationships to be defined by the many, relatively small ecoregions.

Although the Küchler ecoregions define natural vegetation categories, our data suggest that this system does not always provide the highest degree of internal floristic consistency among the three ecoregion systems, as indicated by relatively low Jaccard similarity coefficient values. This lack of floristic consistency might, in part, reflect differences between the classification of the potential natural vegetation in the Küchler system, which is defined by plant life form and one or more dominant plant genera (Küchler 1964), and the observed woody plant species distributions, which are the basis for our species richness and Jaccard similarity coefficient analysis. The focus on dominant genera in the Küchler classification system might mask underlying variability in total woody species composition across the Küchler ecoregion types, which would result in lower mean Jaccard similarity coefficient values for individual ecoregions.

\section{WWF Ecoregions}

Of the three ecoregion systems examined here, the WWF system is the most conceptually heterogeneous. The WWF used a number of ecoregion classification systems as the basis for its global ecoregion scheme (Olson and others 2001). The three transects used in this study primarily cross the continental United States for which WWF adapted Omernik's (1995b) ecoregions. (A few points on the $45^{\circ} \mathrm{N}$ transect fall in Canada for which WWF adapted Wiken and others' (1989) ecoregions of Canada, but we will limit our discussion here to Omernik's classification system). Omernik used a variety of variables in defining ecoregions, including Küchler's potential natural vegetation, climate, physiography, geology, land use, and soils (Omernik 1987). Notably, Omernik recognized that "the importance of each factor in determining the character of ecosystems varies from place to place" (Omernik 1987 , p. 119) so that one ecoregion can be defined using land use as a primary criteria while another considers climate more strongly. These complexly defined ecoregions have then been further modified by
WWF to reflect assemblages of species and ecological communities of conservation interest.

Given the complex way in which WWF ecoregions have been defined, it is hard to predict how they might correspond to the elevation, bioclimatic, and floristic data examined here. In general, the WWF ecoregions exhibit relatively narrow, unimodal distributions of MTCO and GDD5, suggesting a greater degree of internal consistency for these bioclimatic variables. The moisture index for WWF ecoregions tends to be well constrained in relatively moist regions of the eastern United States and less well constrained in the drier West. The WWF ecoregions also display a relatively high degree of floristic consistency along all three transects. The relatively high internal consistency may also be the result of WWF's efforts to modify the Omernik ecoregions to better capture plant species richness patterns of conservation interest.

\section{Bailey Ecoregions}

The Bailey ecoregions are based on a classification system that is more explicitly hierarchical than the Küchler or WWF ecoregion classification systems. Bailey based his coarsest-scale ecoregions, called domains, on broad-scale, continental patterns of climate, defining only three climate domains to cover the entire continental United States. These macroclimate domains were divided into finer-scale ecoregions, called divisions, based on moisture (e.g., seasonality of precipitation or degree of dryness) and temperature (e.g., degree of cold) (Bailey 1998). The next finer spatial scale of ecoregions (provinces) were defined according to plant life form and are the ecoregions we examined in this work. In general, the Bailey province-level ecoregions have fairly tightly constrained moisture index values in the humid East, although broader distributions of the moisture index in the West along each of the three transects (Figures 5, 9, and 13). Bailey ecoregions have less tightly constrained, generally bimodal distributions of MTCO and GDD5 (especially in arid and semiarid regions). These less coherent bioclimate distributions might be a result of the relatively large size of the Bailey ecoregions (relative to the Küchler and WWF ecoregions) such that they encompass larger ranges of MTCO and GDD5.

The Bailey ecoregions, in general, tend to have slightly lower within-ecoregion mean Jaccard similarity coefficients than the Küchler ecoregions along all three transects. The explanation for this difference might be in the way that vegetation is classified within the Bailey system. Bailey defines his provinces based on community structure (e.g., open woodland) and plant 
life form (e.g., broadleaved trees), which does not correspond well to the species-level richness data. Bailey's ecoregions might also show less internal floristic consistency because they tend to be larger and thus might cover a larger number of species than the Küchler ecoregions.

\section{Choosing Among Ecoregion Classification Systems}

Deciding which ecoregion classification system to use for any particular purpose depends not only on the ultimate goal of the individual user but also on an understanding of the original goals and methodologies used in developing each classification system. Consider how each of the three ecoregion classification schemes used in this study incorporates vegetation. The Küchler ecoregions are based on potential natural vegetation patterns. A user interested in modern habitat distributions, however, might want to use a system that included modern vegetation distributions and land-use patterns. At the province level, Bailey used plant life form, not individual species or communities, in defining ecoregions and also a much more systematic and hierarchical approach to classifying ecoregions than either Küchler or WWF. The Bailey ecoregion system might be best suited for studies or management situations that require that all ecoregions are defined according to the same set of criteria. In contrast, the WWF ecoregions for the continental United States are based on Omernik's ecoregions but have been modified by WWF as needed to capture patterns of biodiversity and habitat deemed important for conservation goals. WWF defines ecoregions as "relatively large units of land containing a distinct assemblage of natural communities and species, with boundaries that approximate the original extent of natural communities prior to major land-use change", (Olson and others 2001, p. 933). In certain cases where species assemblages are relatively the same over large areas, it is difficult to define distinct ecoregions based on differences in species assemblages. In these areas, the WWF system might not use species or community assemblages data at all, instead relying on processes such as disturbance regimes or patterns of vertebrate migrations to define ecoregions (Olson and others 2001). The WWF ecoregion classification might be of most use to individuals and organizations that have conservation goals at the same taxonomic resolution as those of the WWF. The Nature Conservancy, for example, uses a modified version of the Bailey classification system for the continental United States, but uses WWF ecoregions for its conservation planning activities in other regions of the globe (Groves and others 2000).
Although some of the environmental variables examined in this study did a relatively good job of characterizing ecoregions along certain parts of the three transects (e.g., the moisture index and ecoregions in eastern North America), other ecoregions were not well described by the elevational, bioclimatic, and floristic variables. Future research might improve on this study's results in two ways. First, different environmental variables might better characterize the ecoregions of one or more of the ecoregion classification systems examined in this study (e.g., using actual evaporation instead of a moisture index). Multivariate analyses might be particularly useful in defining the environmental characteristics of ecoregions. Second, the spatial resolution of both the ecoregions and environmental data must be commensurate. Smaller ecoregions than the ones examined in this study are being defined for both the Omernik and Bailey ecoregion classification systems, which might allow for a better correspondence between these finer-resolution ecoregions and certain environmental variables.

\section{Acknowledgments}

We thank R. R. Schumann and D. Van Sistine for their assistance in obtaining and analyzing the GIS coverages used in this research. R. G. Bailey graciously provided us with the GIS coverage of his most recent compilation. David Olson and Colby Loucks (WWF) provided us with the GIS coverage of the World Wildlife Fund ecoregions for North America. We thank Peter Van de Water for his discussions on the topics considered here. We also thank Tom Loveland, Dan Muhs, Alan Weakley, and an anonymous reviewer for their careful scientific reviews of this manuscript. Funding for this research was provided by the US Geological Survey Earth Surface Dynamics Program.

\section{Literature Cited}

Bailey, D. K. 1970. Phytogeography and taxonomy of Pinus subsection Balfourianae. Annals of the Missouri Botanical Garden 57:210-249.

Bailey, R. G. 1983. Delineation of ecosystem regions. Environmental Management 7:365-373.

Bailey, R. G. 1984. Testing an ecosystem regionalization. Journal of Environmental Management 19:239-248.

Bailey, R. G. 1997. Map: Ecoregions of North America (rev.), scale 1:15,000,000. US Department of Agriculture, Forest Service, Washington, DC.

Bailey, R. G. 1998. Ecoregions map of North America: Explanatory note. Forest Service Miscellaneous Publication 
1548. US Department of Agriculture, Washington, DC, 10 pp.

Benson, L., and R. A. Darrow. 1981. Trees and shrubs of the southwestern deserts, 3rd ed. University of Arizona Press, Tucson, Arizona, 416 pp.

Critchfield, W. B., and E. L. Little Jr. 1966. Geographic distribution of the pines of the world. Forest Service Miscellaneous Publication 991, US Department of Agriculture, Washington, DC, $97 \mathrm{pp}$.

Edwards, M. 1992. Global gridded elevation and bathymetry in J. Kineman, M. A. Ohrenschall (eds.), Global ecosystems database, version 1.0 [CD-ROM]. Documentation manual, Disc A: National Geophysical Data Center, Key to Geophysical Records Documentation 26 [incorporated in Global Change Database, Volume 1. National Oceanic and Atmospheric Administration, Boulder, Colorado, pp A141-A14-4].

Groves, C., L. Valutis, D. Vosick, B. Neely, K. Wheaton, J. Touval, and B. Runnels. 2000. Designing a geography of hope: A practitioner's handbook for ecoregional conservation planning, 2nd ed. The Nature Conservancy, Arlington, Virginia.

Jaccard, P. 1908. Nouvelles recherches sur la distribution florale. Bulletin de la Société Vaudoise des Sciences Naturelles 44:223-270.

Küchler, A. W. 1964. Potential natural vegetation of the conterminous United States (with separate map at scale 1:3,168,000). Special Publication No. 36. American Geographical Society, Washington, DC.

Küchler, A. W. 1973. Problems in classifying and mapping vegetation for ecological regionalization. Ecology 54:512-523.

Küchler, A. W. 1985 (revised from 1966). Potential natural vegetation, 1:7,500,000 scale. National Atlas of the United States. Department of the Interior, US Geological Survey, Reston, Virginia.

Küchler, A. W. 1993. Potential natural vegetation of the conterminous United States. Global Ecosystems Database Version 2.0. Digital vector data in an Albers Equal Area Conic polygon network and derived raster data on a $5 \mathrm{~km}$ by $5 \mathrm{~km}$ Albers Equal Area $590 \times 940$ grid. One independent and one dependent single-attribute spatial layer, 3,580,905 bytes in 13 files. National Oceanic and Atmospheric Administration, National Geophysical Data Center, Boulder, Colorado.

Little, E. L. Jr. 1971. Atlas of United States trees, volume 1, Conifers and important hardwoods. Forest Service Miscellaneous Publication 1146. US Department of Agriculture, Washington, DC.

Little, E. L. Jr. 1976. Atlas of United States trees, volume 3, Minor western hardwoods. Forest Service Miscellaneous Publication 1314. US Department of Agriculture, Washington, DC.

Little, E. L. Jr. 1977. Atlas of United States trees, volume 4, Minor eastern hardwoods. Forest Service Miscellaneous Publication 1342. US Department of Agriculture, Washington, DC.

Little, E. L. Jr. 1978. Atlas of United States trees, volume 5, Florida. Forest Service Miscellaneous Publication 1361. US Department of Agriculture, Washington, DC.
Little, E. L. Jr. 1981. Atlas of United States trees, volume 6, Supplement. Forest Service Miscellaneous Publication 1410. US Department of Agriculture, Washington, DC.

Newman, J. E. 1980. Climate change impacts on the growing season of the North American "corn belt". Biometeorology 7:128-142.

Olson, D. M., E. Dinerstein, E. D. Wikramanayake, N. D. Burgess, G. V. N. Powell, E. C. Underwood, J. A. D'Amico, H. E. Strand, J. C. Morrison, C. J. Loucks, T. F. Allnutt, J. F. Lamoreux, T. H. Ricketts, I. Itoua, W. W. Wettengel, Y. Kura, P. Hedao, and K. Kassem. 2001. Terrestrial ecoregions of the world: A new map of life on Earth. BioScience 51:933-938.

Omernik, J. M. 1987. Ecoregions of the conterminous United States. Annals of the Association of American Geographers 77:118-125.

Omernik, J. M. 1995a. Ecoregions: A framework for managing ecosystems. George Wright Forum 12:35-51.

Omernik, J. M. 1995b. Level III ecoregions of the continent, 1:7,500,000 scale. US Environmental Protection Agency, National Health and Environmental Effects Research Laboratory, Washington, DC.

Powell, J. W. 1878. Report on the lands of the arid region of the United States, with a more detailed account of the lands of Utah. US Congress, 45th, 2d session, House Executive Document 73, 195 pp.

Prentice, I. C., W. Cramer, S. P. Harrison, R. Leemans, R. A. Monserud, and A. M. Solomon. 1992. A global biome model based on plant physiology and dominance, soil properties and climate. Journal of Biogeography 19:117-134.

Ricketts, T. H., E. Dinerstein, D. M. Olson, C. J. Loucks, W. Eichbaum, D. DellaSala, K. Kavanagh, P. Hedao, P. T. Hurley, K. M. Carney, R. Abell, and S. Walters. 1999a. Terrestrial ecoregions of North America: A conservation assessment. Island Press, Washington, DC, $495 \mathrm{pp}$.

Ricketts, T. H., E. Dinerstein, D. M. Olson, and C. Loucks. 1999b. Who's where in North America? Patterns of species richness and the utility of indicator taxa for conservation. BioScience 49:369-381.

Schweitzer, P. N. 1994. ANALOG: A program for estimating paleoclimate parameters using the method of modern analogs. US Geological Survey Open-File Report 94-645, $17 \mathrm{pp}$.

Thompson, R. S., K. H. Anderson, and P. J. Bartlein. 1999a. Atlas of relations between climatic parameters and distributions of important trees and shrubs in North AmericaIntroduction and conifers. US Geological Survey Professional Paper 1650-A, 269 pp.

Thompson, R. S., K. H. Anderson, and P. J. Bartlein. 1999b. Atlas of relations between climatic parameters and distributions of important trees and shrubs in North America-Hardwoods. US Geological Survey Professional Paper 1650-B, 423 pp.

Thompson, R. S., K. H. Anderson, P. J. Bartlein, and S. A. Smith. 2000. Atlas of relations between climatic parameters and distributions of important trees and shrubs in North America-Additional conifers, hardwoods, and monocots. US Geological Survey Professional Paper 1650 C, 386 pp. 
Thornthwaite, C. W., and J. R. Mather. 1955. The water balance. Publications in Climatology 8:1-104.

Thornthwaite, C. W., and J. R. Mather. 1957. Instructions and tables for computing potential evapotranspiration and the water balance. Publications in Climatology 10:181-311.

USGS (US Geological Survey), University of Nebraska-Lincoln, and the European Commission's Joint Research Centre. 1997. Monthly NDVI composites (North America): Global Land Cover Characterization (GLCC) Data-Version 1, 1-km spatial resolution. http://edcdaac.usgs.gov/ glcc/glcc.html.

Wiken, E. B., C. D. A. Rubec, and G. R. Ironside. 1989. Terrestrial ecoregions of Canada. Provisional map 1:7,500,000.
Sustainable Development Branch, Environment Canada, Ottawa, Canada.

Willmott, C. J., J. R. Mather, and C. M. Rowe. 1981. Average monthly and annual surface air temperature and precipitation data for the world. Part 2. The Western Hemisphere. Publications in Climatology 34:1378.

Willmott, C. J., C. M. Rowe, and Y. Mintz. 1985. Climatology of the terrestrial seasonal water cycle. Journal of Climatology 5:589-606.

Yang, T. W. 1970. Major chromosome races of Larrea in North America. Journal of the Arizona Academy of Science $6: 41-45$. 